\title{
Med til en stor Opgaves Losning.
}

\section{Af Orla Buhl.}

Da jeg engang, nogen Tid efter Genforeningen, talte med daværende Stiftamtmand i Haderslev Kammerherre Haarlev, der lige var afgaaet som Administrator for de sønderjydske Landsdele. spurgte han mig, om jeg ikke saa paa det ligesom han, at han og jeg havde haft de mest interessante Opgaver under Genforeningsperioden, og - føjede han til - af os to har De iøvrigt haft den mest interessante, fordi De kom først.

Dertil kunde jeg med Sandhed svare bekræftende og gøre det uden Kommentarer. Jeg vidste, at Spørgeren med sit nøje Kendskab til Forholdene ikke, i hvert Fald ikke specielt, tænkte paa, at jeg var blevet valgt til juridisk Direktør og eneste nordfra hentede Medlem af Ledelsen for en Kreditforening, som netop den Gang skulde paabegynde sin betydningsfulde Virksomhed, og hvis Start jeg i mange Maaneder, før Samtalen fandt Sted, havde været med til at forberede.

Jeg var klar over, at det, som Haarlev saa paa som særligt interessant for mit Vedkommende var, at jeg gennem denne Udnævnelse og forlods Tilstedekomst længe før Genforeningen havde faaet og udnyttet en ved min Antagelse tilsigtet Lejlighed til at være med under Tilrettelægningen af de fleste af Genforeningens økonomiske Foranstaltninger. Haarlev og jeg førte jævnlig Konferencer, idet vi ofte mere eller mindre tilfældigt kom til at følges ad i Toget fra Ringkøbing til København eller omvendt. Han kendte jo ogsaa saa godt som nogen det Tempo, hvori det foregik, et Tempo, der inden for Statsstyret næppe nogensinde har været eller vil blive overgaaet med Udsigt til at se gode Resultater i grødeberedt Jord. Tempoet var jo saaledes, at man kunde tænke sig - hvad jeg f. Eks. m. H. t. Laanekassen havde oplevet - at en for Landsdelens Ve og Vel afgørende Idé, 
der under Genforeningens Forberedelse var fremsat om Morgenen, hvis den i Løbet af Formiddagen vandt $\mathrm{H}$. P. Hanssens Bifald, inden Middag kunde være forelagt og tiltraadt af vedkommende Fagminister og dermed faktisk knæsat som Lov, idet Passagen gennem det sønderjydske Udvalg dermed var beredt og Rigsdagens Vedtagelse givet, naar Formaliteterne efter Genforeningen en Gang skulde bringes i Orden. Et næsten eventyrligt Forhold.

Men hvorfor blev det saa netop mig, der fik denne fine Chance. Det kan der være al Anledning til at spørge om. Det kunde skyldes, man kan næsten sige, at det burde skyldes et forudliggende af mig ydet betydningsfuldt Arbejde i den sønderjydske Sag. Naturligvis kan man ikke have haft den mindste Tilknytning til sønderjydsk fødte Slægter uden at have følt varm Interesse med de udelukkede, men jeg har ikke paa noget Omraade gennem Skrift, Tale eller Handling gjort mig fortjent til denne særlige Gunst, og jeg har i hvert Fald ikke trængt mig paa eller oprindeligt blot antydningsvis meldt mig selv til Opgaven. At det da kunde blive mig, vil ingen have let ved at forstaa. Tilbage som Forklaring, hvis jeg selv skal give en saadan, er - da jeg ikke er overtroisk - kun den, at min Tilkaldelse til Opgaven skyldtes en ren Tilfældighed. Men jeg maa erkende, at da det hele var fuldbragt, sagde jeg til min Kone: Jeg har i den Sag været spurgt om mange Ting og tror at have kunnet svare rigtigt paa det alt sammen, men jeg har næsten Følelsen af, at jeg dermed er udtømt, d. v. s. at jeg har været spurgt om alt, hvad jeg vidste, saa jeg kunde fristes til at tro, at alle de mange forskellige Opgaver, som jeg i mit tidligere Liv har været med til at løse, og hvorfra jeg har de udnyttede Erfaringer, har været tilrettelagt for denne Opgave. -

Tilfældigheden, som jeg dog vil holde mig til, indledes, da Martin Hammerich nogle Aar før Verdenskrigen af 1914 blev Herredsfuldmægtig i Lemvig. Jeg sad den Gang i en relativ stor Sagfarervirksomhed med dertil tilsluttet Deltagelse i lokale 
Raad, Ledelser og Bestyrelser. Da Hammerich jævnligt kom og hyggede sig $\mathrm{i}$ vort $\mathrm{Hjem}$, fik han, ligesom gennem sin Gerning paa det offentlige Kontor, rig Lejlighed til at følge min Form for Varetagelse af Interesserne for den Del af Befolkningen, der, u. H. t. om jeg var Ven eller Fjende, søgte mig, naar det rigtigt kneb, naturligvis navnlig naar det drejede sig om okonomiske Forviklinger. Hvor Hammerich selv i sin Gerning kom i Tvivl, søgte han ofte mit Raad.*)

Der var hos Hammerich ingen Tvivl om, at Sønderjylland snart vilde vende tilbage til Moderlandet. Naar dette skete, hævdede han, vilde han være med til Genforeningens Tilrettelægning, derom var der absolut ikke Tvivl skabt i hans Sind. Efterhaanden begyndte han ogsaa at blande min Person ind $\mathbf{i}$ Tingene. Han spurgte mig egentlig ikke, om jeg da vilde være med til at arbejde paa Opgaven, han gik paa Forhaand ud fra, at naar der var Brug for nogen til den Sag, var det givet, at man ligesom han selv - ligegyldigt hvad det ellers kostede - straks var beredt.

Hvad jeg sagde dertil. Nærmest intet. Jeg tog det som venlig Tale. Der var for mig som praktisk Mand alt for mange Eventualiteter i Sagen til, at der var Grund til paa det paagældende Stadium at føle Bekymring og Uro henholdsvis Glæde og Stolthed. Husk paa, at det laa forud for første Verdenskrig.

Imidlertid forlod Hammerich Lemvig, rejste til Skjern og derfra til Stege hos fhv. Statsminister Zahle, der her under en Pavse i hans politiske Lobebane var Borgmester, By- og Herredsfoged. Vi opretholdt dog ogsaa i den Periode Forbindelsen med hinanden. Og saa skete der jo det, at det netop blev Zahle, der skulde forberede Genforeningen, og at denne med H. P. Hanssen hurtigt blev enig om, at Hammerich var den rette Mand til at forestaa det til Forberedelsen oprettede Kontor.

*; Da en Sonderjyde spurgte Martin Hammerich, hvordan er Orla Buhl: citerer Hammerich vist efter en lemvigsk Revu: „Uden Orla Buhl var Lemvig et Hulx. 
Hammerich har senere fortalt mig, at han ret snart havde sagt til H. P. Hanssen, at der var en Mand i Lemvig, Orla Buhl, som under en eller anden Form, der maatte findes, burde knyttes til Opgaven. Selv satte jeg ikke den lykkelige Begivenhed i Forbindelse med Hammerichs tidligere Udtalelser. Den Gang intereserede jeg mig - husker jeg - ud fra mine Erfaringer som Skatteraadsformand særligt for Landbrugsbeskatning under en generelt virkende Form for retfærdig og fyldestgørende Fordeling, en i sig selv ganske enkelt Form, der faktisk af Landsoverskatteraadet blev anerkendt og gennemført i Praksis og bruges den Dag i Dag.

Formen, som jeg indledede, bødede paa den i Skattelovens (af 1903) faktisk anviste Præmie paa Udygtighed og Dovenskab.

Det første jeg, efter at Hammerich havde overtaget Ledelsen af sønderjydsk Ministerium, hørte fra ham, var et Brev om mit Syn paa Amtmand Haarlev i Ringkøbing, navnlig om jeg vilde anse denne kvalificeret til Opgaven som Administrator i Overgangsperioden. H. P. Hanssen havde bedt Hammerich om at undersøge det. Der var ogsaa Tale om to andre Amtmænd, skrev han. Jeg kunde ubetinget anbefale Haarlev. Om mit Svar var afgørende, ved jeg ikke, men det blev Haarlev. Og saa kom til min Forbavselse ret hurtigt derefter en Forespergsel, om jeg vilde være administrerende Direktør i en Kreditforening, som man ønskede oprettet $i$ Landsdelen. Hammerich mente, at hvis jeg blot omgaaende sendte ham en Skrivelse om, at jeg var villig til at paatage mig Opgaven, vilde det paa H. P. Hanssens og hans egen Anbefaling mest sandsynligt blive mig.

Jeg var egentlig ikke i Tvivl om, at det skulde jeg holde mig fra. Navnlig efter at jeg - der paa Grund af Kravet om hurtigt Svar straks havde svaret nogenlunde imødekommende - mere indgaaende havde drøftet Sagen med min Kone og Kompagnon. Mine Betænkeligheder havde jeg parat fra et tid- 
ligere Tilfælde inden for samme Fag. Ganske vist havde jeg Interesse for Faget. Men navnlig Interesse for at faa indført visse betydningsfulde Reformer, som jeg gennem min Praksis og som Sagfører for saadanne Institutioner havde indset Betydningen af. Oprindeligt var den Interesse muligt vakt, fordi der i begge mine Forældres Slægter havde været fremtrædende Stiftere af Realkreditinstitutioner.

Men ogsaa Sagens Vrangside havde jeg nogle faa Aar forud haft Lejlighed til at gøre mig klar.

Da den adm. Direktør for Vest- og sønderjydsk Kreditforening, Kammerherre Hoppe, var død, blev jeg af tre Medlemmer af dens Repræsentantskab spurgt, om jeg vilde være hans Efterfølger. I saa Fald mente de at kunne gennemføre mit Valg. Jeg takkede, men afslog omgaaende. Min Stilling var den Gang, efter at Startvanskelighederne var tilbagelagt, saa vel underbygget, som en saadan kan være. Der, hvor jeg sad, var jeg ikke underkastet en bestemt Forsamlings Vilkaarlighed, noget, der altid har været min Rædsel paa Grund af min Tilbøjelighed til at sige min Mening u. H. t., om den falder i Bjærgets Smag. Dertil kom, at jeg den Gang havde stigende og større Indtægt, end den nye Stilling kunde yde, og navnlig var jeg ikke her paa Valg hvert 5. eller 6. Aar, saaledes som Skik var i Ringkøbing. Jeg kendte jo Laantagernes og Repræsentanternes Snak, naar Direktionen ikke fulgte Ønskerne: f. Eks. „D'Hr. i Direktionen glemmer vist, at de snart skal paa Valg, og at det er os, der bestemmer, hvordan det falder ud". Og som jeg sagde til de mig venligtsindede Mænd, der spurgte. Jeg er faktisk sikker paa ikke at blive genvalgt, fordi jeg straks vil forsøge at faa gennemført Reformer, som kommer Repræsentanterne paa tværs.

Det, som jeg i den Henseende navnlig tænkte paa, var Afskaffelsen af den Skik, at Repræsentanterne mod Betaling ordrede Debitorernes Laan og saaledes selv var interesserede $\mathbf{i}$ 
Laanehøjden, som de havde afgørende Indflydelse paa. En Form, Sønderjyllands Kreditforening lykkeligvis har taget Afstand fra.

Jeg slog altsaa straks fast overfor Mændene, at saa snart jeg havde vist Interesse for en saadan Reform, vilde jeg have været færdig ved første Periodes Udløb.

Men der var ogsaa andre og mere betydningsfulde Reformer (der ikke her skal drøftes), som jeg i saa Fald vilde tage op for muligt ogsaa derigennem at løbe Panden mod Muren, hvis jeg lod mig indrullere.

$\mathrm{Nu}$ er man jo ikke valgt, fordi 3 Repræsentanter spørger, men at netop disse Mænd havde Indflydelse paa Sagen fremgaar af, at da jeg foreslog de samme Mænd i Stedet for mig at kaste sig over Fuldmægtig, faktisk Kontorchef i Kreditforeningen, Troensegaards Valg, blev det ham. Han havde paa det Tidspunkt end ikke været paa Tale og navnlig ikke selv fremsat noget Ønske, og da det kom saa vidt, maatte jeg selv rejse til Ringkøbing for at faa ham til at gaa med dertil. Han bad sig fri, han onskede langt hellere mig og forsikrede - hvad ogsaa blev oplyst fra anden Side - at jeg var Favorit. Men han lod sig dog overtale. - Det viste sig desværre efter den Afslutning, denne udmærkede, gennemredelige Mand fik paa sit Arbejde der, at han havde set rigtigt i ikke at ønske Pladsen. Han led nemlig den Skæbne, jeg havde forudset for mig selv og undgaaet. Iøvrigt saa og ser jeg saaledes paa det, at det er af Betydning for Institutionen, at der er Mulighed for, at Funktionærerne gennem deres Interesse for Arbejdet kan naa ogsaa dens højeste Post. Det er en Kilde til Dygtiggørelse. Og selv om det kun kan naas af en enkelt ad Gangen, giver ogsaa denne Stigning Avancementsmulighed hele Rækken igennem.

Nogle, men ikke alle, af disse mine Ræsonnementer kunde anvendes i Forhold til Brevet fra Haderslev. Jeg havde ganske vist paa faa Linier skrevet en „Ansøgning“ om at blive Direktør (Ordet administrerende, som Kravet lød paa, brugte jeg dog vist ikke), 
men denne Henvendelse lod jeg senere efterfølge af et Brev til Hammerich, hvori jeg meddelte mineBetænkeligheder ved at maatte flytte til Haderslev for at kunne være Direktør i Kreditforeningen. Forholdene var for usikre til, at jeg - som det laa og af Hensyn til min Familie - havde Lov dertil. Naar jeg ikke vilde til Ringkøbing, var det ikke af Frygt for ikke teknisk at kunne klare Posten, det var vel gaaet, men derimod er jeg ikke i Tvivl om, at det at være adm. Direktør i Sønderjylland ikke havde ligget for mig. - Den Opgave skulde i hvert Fald i første Omgang røgtes af en Sønderjyde, og af Sønderjyder kender jeg den Dag i Dag kun Callø, der kunde have klaret den. Her har der været Brug for alle hans Egenskaber.

Jeg bør dog her tilføje, at jeg hurtigt gjorde den Erfaring, at det ikke vilde blive Repræsentantskabet i Sønderjylland, der vilde have beredt mig Vanskeligheder, hvis jeg ellers klarede Tingene. Dette kan ikke være bedre. Min Mening om den Forsamling er kendt nok. Det er Forholdet til Sønderjyderne iøvrigt, som i hvert Fald jeg ikke vilde have kunnet klare. Om Repræsentantskabet kom jeg hurtigt til at udbryde, at det var Danmarks bedste. En Udtalelse, som Callø ofte citerede.

Til øvrige Betænkeligheder kommer, som jeg mener det og sagde det i min Afskedstale: jeg egner mig ikke som Forgrundsfigur, bl. a. interesserer det mig ikke at være det. Paa Nr. 2Pladsen har man Ret til at tie og bedre Tid til at tænke.

Imidlertid behøvede jeg altsaa ikke at have afvist Forslaget om at blive adm. Direktør.

Paa mit Brev til Hammerich fik jeg ret omgaaende det Svar, at det var godt nok, at jeg ikke vilde være adm. Direktør, thi, som Hammerich oplyste, nu havde Callø meldt sig til denne Post, og ham kunde og vilde man ikke udenom. Callø er ikke Jurist, skrev han, men kunde De ikke tænke Dem at ville overtage Stillingen som juridisk Direktør. Han tilføjede, at Lønnen for denne Opgave, som jeg jo selv vidste, efter Sædvane kun vilde blive Halvdelen af den adm. Direktørs Løn (fra 
anden Side blev antydet 8000 henholdsvis $4000 \mathrm{Kr}$., hvad dog blev overskredet), men, tilføjede Hammerich, De kan jo da drive Sagførervirksomhed i Haderslev ved Siden af. $\mathrm{Da}$ jeg end mindre kunde forsvare at flytte til Haderslev og opgive Lemvig paa Basis af den ringere Stilling, og da jeg navnlig undrede mig over, at Hammerich kunde mene, at man kan forene Sagfører- og Kreditforeningsvirksomhed i samme Kreds (skrive Ansøgning om Formiddagen og bevilge den om Eftermiddagen), svarede jeg foreløbigt ikke derpaa, idet jeg altsaa henholdt mig til det tidligere Svar, der faktisk var et Afslag, fordi jeg ikke vilde flytte.

Imidlertid skete der det, at jeg en af de paafølgende Dage (i Herning) traf Amtmand Haarlev under et Møde $i$ en Jernbanebestyrelse, hvor vi begge sad. Han fortalte da - hvad jeg altsaa uden hans Kendskab vidste - at han skulde være Administrator i Overgangstiden. Jeg fortalte til Gengæld ham om den Henvendelse, jeg havde haft og nærmest afslaaet. Dertil svarede han meget absolut, at det havde jeg aldeles ikke Lov til. Det var, sagde han, for det første en saa ærefuld Opfordring og en saa betydningsfuld Opgave, at jeg ikke kunde afvise den under Hensyn til et nok saa stort okonomisk Offer. Og, tilføjede han, med Deres konstruktive Evne og praktiske Kendskab til danske Forhold kan netop De være til den allerstørste Nytte for Landsdelen. Her har - paastod han - Hammerich set helt rigtigt. Han bemærkede, at han en af Dagene skulde træffe Jul. Nielsen og vilde da have Lov til at sige til ham, at jeg var villig til at overtage Posten som juridisk $\mathrm{Di}^{-}$ rektør. Jeg takkede Haarlev, men mente, at Pladsen var besat. Imidlertid tog jeg det Løfte af ham, at hvis dette ikke var Tilfældet, og hvis min Kone tiltraadte det, vilde jeg bede ham tale med eller skrive til Jul. Nielsen, hvilket jeg ogsaa ret omgaaende bad ham gøre. - Tilfældigvis var 3die Pladsen endnu ubesat. Paa et Møde, som den Gang var afholdt, og hvor det var Meningen at vælge alle 3 Direktører, var kun Callø og 
Hansen valgte. Besættelsen af den 3die Post, til hvilken jeg vist end ikke havde været paa Tale, var — altsaa ret tilfældigt - blevet udskudt.

At Haarlev, som jeg altsaa havde bedt ham om, havde skrevet til Jul. Nielsen, fik jeg senere bekræftet, thi længere Tid derefter fortalte Haarlev mig, at Jul. Nielsen, der iøvrigt vist end ikke selv havde stemt paa mig, havde takket ham, fordi Haarlev her havde anvist den rette Mand, som de, havde han sagt, var glade ved at have faaet knyttet til Sagen.

Efter det Puf, Haarlev havde givet mig, svarede jeg Hammerich, at jeg gerne vilde overtage Stillingen som jur. Direktør, og han satte mig da i skriftlig Forbindelse med Refslund Poulsen og I. H. Schmidt, ligesom jeg senere fik at vide, at Hammerich stærkt havde paavirket de to Mænd til at arbejde for mit Valg. Og jeg er klar over, at uden de to Mænds direkte Paavirkning af alle Stiftelsesudvalgets Medlemmer var jeg gaaet Glip af det ærefulde Hverv.

Jeg fik et venligt Brev fra Refslund Poulsen, hvori han oplyste om fornævnte 1. Mødes Resultat og Drøftelser og meddelte, at han mente, at hvis jeg vilde have den paagældende Post, altsaa som juridisk Direktør, vilde man vist kunne mødes i dette Resultat.

Inden jeg tog Standpunkt, forsøgte jeg dog at komme over Grænsen for at tale personligt med Refslund Poulsen, men det var paa det paagældende Tidspunkt umuligt. Jeg blev stoppet ved Grænsen, Derimod fik jeg Refslund Poulsen til at møde mig i $\varnothing$ dis, og her spurgte jeg, om det kunde ordnes saaledes, at jeg samtidig med, at jeg valgtes til Direktør forblev boende i Lemvig og saaledes, at jeg i hvert Fald var med til Starten, som meget vilde interessere mig. Under den Form kunde vi jo eventuelt efter Stiftelsen skilles som Venner og jeg tage tilbage til Lemvig, hvis det viste sig, at vi ikke passede sammen. - Dette kunde Refslund Poulsen for sit Vedkommende tiltræde, som en foreløbig Løsning, men foreslog iøvrigt, at vi 
ikke gjorde Spørgsmaalet om fortsat Bolig i Lemvig til noget Kabinetsporgsmaal, da det jo kunde bruges imod mit Valg, hvis nogen dertil var indstillet. Dette passede mig godt nok, thi viste der sig senere Utilfredshed med den Ordning, kunde jeg paa den Konto, at man krævede en af mig uønsket Flytning i god Orden trække mig tilbage til Lemvig. Ligesom D'Hrr., hvis de ønskede mig fjernet, kunde give Bopælsforholdene Skylden.

Samtidig spurgte jeg Refslund Poulsen, hvorfor man vilde begrænse sig til at være Landkreditforening, hvorfor ikke tage Byerne med og have to Strenge paa Buen til at spille paa. Det havde Callø ogsaa talt om, svarede Refslund Poulsen. Det var jo derfor uheldigt, at Ny jydske Købstadkreditforening havde faaet Tilsagn om at maatte gaa der ned. $\mathrm{Da}$ jeg senere fik Brev og Dokumentudkast, Brevpapir o. s. v. med den paatænkte Kreditforenings Titel som „Ny sønderjydsk Landkreditforening“, gjorde jeg opmærksom paa, at de tre Ord indeholdt hver sin, altsaa ialt tre Fejl. Man bør, skrev jeg, ikke kalde en Institution, som skal virke længe, og som bliver solidere med Alderen, for „Ny“. - Man bør ikke bruge Ordet „sønderjydsk“, da dette indeholdes i „Vest- og sønderjydsk Kreditforening", hvormed Mulighederne for Forveksling vil øges, og Ordet "Landkreditforening“ maa jo udgaa, da jeg gik ud fra, at Byerne kom med som Laaneobjekter.

Jeg foreslog derimod Betegnelsen „Sønderjyllands Kreditforening", og Navnet blev straks uden videre fastslaaet. Der er Klang og Balance i dette Navn, saaledes er der lige mange Bogstaver i begge Ordene.

Nogen Tid efter Mødet med Refslund Poulsen fik jeg da Brev fra Julius Nielsen om, at jeg (som det viste sig med et lille Overskud i Stemmer) var valgt til juridisk Direktør.

Derefter fik jeg som min første Opgave Anmodning fra Callø om at komme til København, for at vi kunde ordne os med en Bankforbindelse. Og han og jeg traf da hinanden paa 
et halvmørkt Værelse i Grundtvigs Hus. Callø meddelte mig, hvad angik Bankforbindelsen, som vi skulde søge, at han, hvis jeg ikke havde anden Plan, helst saa, at det blev Landmandsbanken. Uden Begejstring svarede jeg, at det havde jeg egentlig ikke. Jeg havde den Gang som Bankdirektør haft Forbindelse med Handelsbanken og faaet fin Behandling der, da min Bank netop havde Brug for Tillid. Privatbanken havde jeg ikke den Gang haft videre at gøre med. Men iøvrigt var den Bank for Vest- og sønderjydsk Kreditforening (ligesom Handelsbanken havde Viborg), og alene dette udelukkede den. Landmandsbanken havde jeg overhovedet aldrig haft med at gøre, og hvad jeg havde hørt om Dispositioner, der kunde føre til hvad som helst, var, selv om Kilden plejede at være paalidelig, paa dette Tidspunkt saa svævende, at jeg ikke havde I.ov til at bygge noget derpaa. Glückstadt stod endnu den Gang i sin fulde, men maaske lidt for stærkt lysende Glans. - (Og som det gik, var det jo heldigt nok, at det netop blev Landmandsbanken. Gennem Handelsbanken var vi ikke sluppet over til Nationalbanken. Den havde ikke givet os Berettigelsen til at smække Døren i, som vi gjorde, da vi gik efter den sidste Konference der).

$\mathrm{Vi}$ aftalte saa at mødes næste Dag for at gaa i Landmandsbanken.

Her blev vi modtaget af Direktor Ringberg. Hans arrogante Form tiltalte mig ikke. Senere forstod jeg, at det var en syg og mærket Mand, vi talte med og lod det være Forklaringen paa, at vi nærmest fik det Indtryk, at Sagen ikke interesserede ham nævneværdigt, hvad dens videre Forløb heller ikke kom til, fordi Banken krakkede, hvad han jo allerede den Gang maa have set Muligheden for.

Han lovede naturligvis, at Banken skulde søge at fremskaffe ,højst mulige“ Kurser, „saa vidt muligt“ lig tilsvarende Institutioner, men derudover lovede han faktisk ikke noget. Jeg blandede mig saa lidt som muligt i den trevne Samtale, dog 
fandt jeg Anledning til at spørge, om han dog ikke kunde give et ubetinget Tilsagn om den betydningsfulde Startkurs, navnlig Kursen paa de $200.000 \mathrm{Kr}$, der skal foreligge solgt, før Kasseobligationer kommer paa Børsen til den Kurs, hvortil disse 200.000 er overtagne. Her vilde han dog noget trevent love en til Vest- og sønderjydsk Kreditforening svarende Kurs, derimod ikke til et Gennemsnit af alle Landkreditforeningers Kurs, som jeg vilde have ham til.

Det havde jo været naturligt under saadanne Forhold at kræve skriftligt Svar, men jeg indsaa, at det vilde kun føre til at faa Forbeholdene yderligere fastslaaet. Derfor fremsatte jeg ikke Kravet, da Callø havde akcepteret.

Jeg husker, at da vi gik fra Landmandsbanken, spurgte Callø, der ogsaa maa have tænkt paa Bekræftelse, om man nu kunde stole paa saadant et Tilsagn. Jeg fortalte ham da, at netop det samme Spørgsmaal havde jeg rettet til min Onkel, forlængst afdøde Overretssagfører A. Th. Buhl i Randers en Gang, vi sammen havde været til Droftelse og faaet et Tilsagn af Geheimeetatsraad (gamle) Dam i Handelsbanken. Da svarede Onklen (idet han paa Forhaand udelukkede Dam) spøgefuldt: „Ved Du ikke, at man siger, at den eneste københavnske Bankdirektør, der er noget længe om at gaa fra sit Ord, er den meget omtalte Direktør $H$., men, tilføjede han, det tager kun længere Tid for ham, fordi han stammer". Og for Resten, tilføjede jeg til Callø, lovede Ringberg jo ikke ret meget, saa det han lovede, maa vi vel kunne tro bliver holdt.

Imidlertid var Banken ikke holdt i Uvidenhed om, at der var truffet en Aftale. Da vi senere paa Dagen henvendte os $i$ en anden Afdeling for at faa en Kassekredit paa indtil 30.000 $\mathrm{Kr}$. til Startudgifter, blev den straks og uden videre Formaliteter eller Underskrift tilrettelagt.

Næste Dag kom den nye Kollega Hans Hansen til Byen, og vi gik sammen op i Indenrigsministeriet for at forhøre, hvor- 
ledes det gik med Tilrettelægningen af Loven for Kreditforeningen.

Vi blev henvist til Fuldmægtig, senere Overpræsident Bülow, der venligt gav os rigtige Oplysninger om Sagen, navnlig at den $\mathrm{f}$. $\mathrm{T}$. beroede hos Kreditforeningernes staaende Fællesudvalg til Erklæring. Inden man hørte derfra, var der ikke mere at tale om, mente han.

$\mathrm{Da}$ det Besøg var overstaaet, foreslog jeg, at vi ogsaa skulde hilse paa Minister Ove Rode. Kan man det her saadan u. v., spurgte Callo. Han oplyste, at i Tyskland varer det flere Dage, og det skal være meget vigtige Sager for at naa frem til Excellensen. - Det skal det ikke her, svarede jeg, for der kommer Ove Rode gaaende, og jeg gik hen til Rode og sagde, hvad det gjaldt. Saa følg efter mig op i Indenrigsministeriet, saa skal jeg sørge for, at d'Hrr. kommer ind med det samme. Og saadan skete det, cg Ove Rode udfoldede al sin Charme, og det betød noget. Navnlig glædede det os at høre Indledningen: Ja, den Sag ligger jo hos Kreditforeningernes staaende Fællesudvalg til Erklæring, men da vi roligt kan gaa ud fra, at man derfra vil lægge den paatænkte Kreditforening alle mulige Hindringer i Vejen, kan vi jo lige saa godt allerede nu drøfte, hvorledes vi trods denne Modstand skal tilrettelægge den af Sønderjyderne ønskede Institution. Ove Rodes venlige Indstilling fremdeles overfor Kreditforeningen fik den allerstørste Betydning for Sagens gode Forløb. Selv en saa mægtig Faktor som den i Ringkøbing valgte I. C. Christensen skjulte ikke, at han paa Ringkøbing Kreditforenings Vegne onskede vor Institution kværket. Og da Vest- og sønderjydsk Kreditforening med gammel Berettigelse havde virket i Sønderjylland og havde sønderjydsk i Navnet, var den store Mand en farlig Fjende. (Havde I. C. været Statsminister den Gang, var der næppe blevet en Kreditforening ud deraf)! Men ogsaa alle andre Kreditforeninger, hvis Kreds havde Berøring med Landsdelen, 
ønskede at faa en Part, d. v. s. at vi skulde uddivideres til Plukfisk.

Jeg husker navnlig en af de mange Gange, hvor vi havde noget at skulle have droftet med Ove Rode og fik ham kaldt ud fra Mødet i Folketinget. Da tog han Callø og mig under hver sin Arm og gik hen $i$ en af Karnapperne. Det drejede sig om Kravet fra andre Kreditforeninger om Anpart i Udlaanet til Landsdelen. Ja, sagde Ove Rode, hvordan klarer vi saa den. Dertil svarede jeg: Hvis jeg var Dem, vilde jeg sige til Ringkøbing, I kan faa Lov til at laane i Tønder Amt, naar Sønderjylland saa maa laane i Ribe Amt, og til Viborg, I kan faa Adgang til Haderslev Amt mod tilsvarende Ret i Vejle Amt og endelig Østifterne Als mod Ret til at komme til Svendborg Amt. Hvis De en anden Gang faar saadanne Ideer Buhl, maa De endelig lade mig dem vide, var Rodes Svar. Jeg troede dog ikke, han brugte Planen. Derimod bad han mig en Gang senere om telefonisk at faa at vide, hvad vi kom efter, naar jeg fra Hotellet meldte Deputationen, hvad ofte skete, naar der havde været Ugler i Mosen. Første Gang jeg telefonisk anmeldte vor Ankomst lige før vi skulde i Ministeriet, spurgte han. Naa, og hvad mener De, jeg skal svare. Det sagde jeg og konstaterede efter Audiensen, at Rode havde en god Hukommelse.

Efter det første Møde hos Rode drøftede vi, Callø, Hansen og jeg, Tingene i Grundtvigs Hus. Udkastet til Statutterne havde Direktør Gjessing (ganske vist som det viste sig, under fuld Udnyttelse af Experten i Genforeningsproblemer Højesteretssagfører Cohn's store Viden) haft under Udarbejdelse. Jeg rejste her Spørgsmaalet, om vi ikke lig Husmandskreditforeningerne skulde søge om Statsgaranti for Renterne. Dette mente Callø ikke, fordi det vilde virke, som om der var en særlig Risiko ved disse Obligationer. Og det var maaske godt, at den af mig foreslaaede Statsgaranti ikke kom den Gang. Den virkede stærkere, da den senere paa Calløs Initiativ blev indført den Gang, Staten maatte træde til. En Hjælpeaktion 
fra Statens Side, der ganske vist gav Staten en Millionfortjeneste, men det blev for Staten i det lange Løb en absolut tvivlsom økonomisk Fordel. Oprindelsen til Hjælpeaktionens Nødvendighed var den, at Staten pludselig paa Vekselerer Henriques' Henstilling lod de til Kursens Stabilisering opkøbte Kasseobligationer bringe paa Markedet, og det dertil selvfølgeligt svarende Kursfald indtraadte omgaaende, saa Støtte maatte ydes. - Altsaa en ganske mærkelig Afslutning paa den oprindelige Hjælpeforanstaltning, der sikkert i sig selv direkte som indirekte havde givet Forslagsstilleren til Udsalget en passende Gevinst.

Endnu mere utidig var dog de Manipulationer, samme søgte og en Tid fik Lejlighed til med Kreditforeningens Reservefondsobligationer, da Hjælpeaktionens Fond var realiseret. $\mathrm{Da}$ jeg fik en Lejlighed til i København at være med til at drøfte Spørgsmaalet om en Fortsættelse af Manipulationerne, paaviste jeg overfor den altid gevinstsikre Mellemmand, at disse Transaktioner, der laa udenfor vor Opgave, for Kreditforeningen indebar en Mulighed for Tab, der kunde bebrejdes os, da de var ganske uden Interesse for Laantagerne, hvorefter de bortfaldt.

Efter det første Møde i København skulde jeg jo gerne til Sønderjylland. Det var imidlertid ikke saa let at ordne paa ordinær Vis. Callø og jeg gik sammen op paa det paagældende Kontor, vist nok det tyske Konsulat i København, og spurgte, om jeg kunde faa Pas. Hvad skal han der efter, blev vi spurgt. Tilrettelægge Genforeningen, svarede Callø. - Tak, det interesserer os ikke.

Der var Tale om, at jeg vist maatte smugles over den endnu lukkede Grænse, men saa gik I. H. Schmidt til den tyske Landraad i Haderslev, og denne udmærkede Mand skrev til Konsulatet i Kolding, at min Nærværelse var ønskelig, og da jeg meldte mig der, oven i Købet efter at Kontoret var lukket Lørdag Eftermiddag, blev jeg først afvist til Mandag, men da 
jeg oplyste, hvem jeg var, anbefalet af Landraaden, sprang alle Døre op, og jeg fik faktisk ubegrænset Ret til at passere Grænsen frem og tilbage, som det passede mig. (Min Kone var derimod, en Gang hun besøgte mig, lige ved paa Grænsen at blive arresteret p. Gr. af manglende Pas og ført til Flensborg. En ung tysk Officer, som hun maa have bedaaret, tog hende imidlertid uden videre under Armen og frelste hende ved at føre hende ud i Mørket til Rutebilen mod Kolding).

Og saa drog jeg da derned og kom til Haderslev en trist, beskidt og mørk, regnfuld Aften, sikrede mig et (ildelugtende) Værelse paa Harmonien, hvor jeg ikke vilde opholde mig længere end nødvendigt, saa derfor en uhyggelig og daarlig tysk Film, inden jeg gik i Seng.

Men næste Dags Morgen, da jeg ringede paa ved Calløs Bolig paa Kreditforeningens Startsted over Haderslev Bank, lukkede Calløs prægtige gamle Far mig op og hilste mig velkommen med de Ord: Naa, det er nok "Manden fra Danmark“. Og hvor var der lunt hos Callø, Fru Callø og deres den Gang kun tre smaa søde Piger.

Næste Dag mødte vi til Møde i Stiftelsesudvalget under Julius Nielsens Forsæde. Jeg skal ikke nægte, at da jeg havde modtaget Udnævnelsen, da jeg rejste derned, og da jeg nu gik til Møde, sagde jeg til mig selv: Hvad er det egentlig, du har indladt dig paa, hvad ved du, som ikke de prøvede Mænd der ved i Forvejen.

Og da jeg saa og hørte Forsamlingen og dens Indlæg i Problemerne, var jeg ganske imponeret ikke alene over, hvad de havde Forstand paa, men navnlig den kloge og koncise Maade, hvorpaa de udtrykte sig, (I endnu højere Grad har jeg ved de mange efterfølgende Repræsentantskabsmøder tænkt det samme. Som Sekretær ved Møderne havde jeg jo rig Lejlighed til at konstatere, at egentlig alt, hvad der blev sagt, burde være skrevet op). Selv blandede jeg mig saa vidt muligt ikke i Drøftelserne. En Holdning, jeg iøvrigt stadig har fast- 
holdt. Men allerede i Stiftelsesudvalget viste det sig at være klog Politik fra min Side.

Efter at nogle Møder var forløbne, sagde Refshauge $\mathbf{i}$ hvert Fald efter et saadant Møde til mig. Nu kender jeg Dem, Direktor Buhl. Jeg forstod Dem ikke rigtigt i Begyndelsen, det, at De sagde saa lidt, undrede mig. De var jo kaldet her ned for at belære os. Men nu har jeg - fortsatte han - opdaget, at saa længe vi siger det, De synes er det rigtige, lader De os tale los. Jeg forstaar, at det ikke er Dem om at gøre at være den, der siger det rigtige, men saa snart De ikke er tilfreds med Gangen i Drøftelserne, gør De saa kort som muligt de nødvendige Bemærkninger for at faa os ind paa rette Spor, og saa tier De igen. Samtidig sagde Refshauge, at han egentlig ikke var med til at byde mig velkommen. De er, sagde han videre, nemlig den eneste, der nogensinde har slaaet mig ud under en Afstemning (altsaa ved Valget af Direktør), men føjede han venligt til: Jeg er efter at have lært Dem at kende kommet til det Resultat, at det var godt, det gik, som det gik, at det blev Dem. En Udtalelse, der naturligvis glædede mig.

Og da Julius Nielsen en Gang ved et Mødes Slutning fandt Anledning til - tilsyneladende ret umotiveret paa det Tidspunkt - at udtale sin Glæde over, at jeg var kommet til, supplerede Callø dette med at udtale ogsaa sin og Hansens Tilfredshed med Valget af mig, idet han navnlig motiverede Anerkendelsen med, at „Buhl træder saa behageligt fast i Gulvet ovre $i$ den røde Bygning“. Senere har Callø Tid til anden anerkendt denne min Evne til ikke alene $i$ den røde Bygning at vinde Gehør for den Opfattelse, Kreditforeningen ønskede anerkendt. Imidlertid tror jeg ikke, at de gode Resultater saa meget skyldtes, at jeg traadte haardt i Gulvet som netop det, at jeg gik stille med Dørene, uden iøvrigt at være imponeret af Stedets Hellighed.

Men Jul. Nielsen, Refshauges og Calløs Udtalelser bidrog jo til, at jeg selv følte, at jeg ikke sad der helt uden Berettigelse. 
$\mathrm{Nu}$ var jeg altsaa med i Laget og kom saa hurtigt og stærkt i Anvendelse, at jeg maatte føle mig tryg over for den Overflødighedsfølelse, som jeg var mødt med.

I Kreditforeningens Starts Interesse maatte jeg jævnligt alene eller sammen med mine Kolleger og de Deputationer, vi maatte have med, naar det rigtigt kneb, rejse strenge Natture; det blev de, da Sovevognene enten var opgivne eller skulde overnatte i Nyborg. Jeg maatte dertil fare fra og til Lemvig, til og fra Haderslev; Haderslev København, København Lemvig og om igen. - Det sled paa Kræfter og Nerver, men hvor var det interessant.

Hovedsagen var naturligvis Kreditforeningens Interesser. Men det var nærmest Sport, saa længe vi var beskyttede af den radikale Regering først og fremmest Ove Rode, og af det sønderjydske Ministerium. Vi kunde altid under ny Rejse til København faa genoprettet, hvad der var brudt ned (eller blevet „traadt $i$ “).

Men ogsaa paa andre Felter havde jeg den Glæde at blive taget paa Raad i Henseende til den Opgave, som Hammerich oprindeligt havde tiltænkt mig.

En af de første Opgaver, jeg blev stillet overfor ud over Problemerne med Kreditforeningens Start, var, saa vidt jeg husker, Valutareguleringen. En Dag, lige før jeg skulde rejse fra København, gav Hammerich mig det i sønderjydsk Ministerium udfærdigede Udkast til Reguleringsreglerne og bad mig udtale min Mening derom. Jeg benyttede Rejsen i Toget opad Vestkysten til at gennemgaa det, og i en Postkasse i Vemb afleverede jeg mine Bemærkninger. Det var en Kritik af næsten hver eneste Post, men hvad den gik ud paa, husker jeg ikke, og Udkastet sendte jeg efter Anmodningen med tilbage. Kort efter fik jeg fra Hammerich Meddelelse om, at H. P. Hanssen havde læst min Kritik med megen Interesse, at Forslaget paa det Grundlag var opgivet, og at H. P. Hanssen gerne 
vilde tale med mig, saa snart det var muligt. Da jeg mødte, gentog H. P. Hanssen sin Anerkendelse af min Kritik og bad mig se paa et nyt Forslag. Det gjorde jeg og gav ogsaa hertil kritiske Bemærkninger, som jeg forstod blev anerkendte. Jeg husker altsaa ikke, hvad det var, jeg fik D'Hrr. til at kassere. Derimod husker jeg, at Hammerich en Søndag, vi var sammen i København, pludselig fortalte, at $\mathbf{H}$. P. Hanssen den Dag talte i Senderjylland. Inden han rejste, havde han spurgt Hammerich, hvad han kunde sige om Valutareguleringen, og Hammerich havde da svaret, fortalte han, at han kunde love, at man fik Erstatning efter Markens Dagskurs paa Udbetalingsdagen, og derefter eftersom Marken steg. Men - svarede jeg - hvis den falder, hvad den vel nok gor, skal der saa betales tilbage? og skal det næste Hold have mindre? Det havde Hammerich ikke tænkt paa. Ja, det duer ikke, erklærede jeg ret brutalt, Hammerich gav mig Ret, og vi var meget spændte paa, hvad H. P. Hanssen havde sagt. Men da han kom tilbage, viste det sig, at $H$. P. Hanssen var gaaet let over Sagen, og intet var blevet refereret.

Jeg blev en anden Gang, da jeg var i København, tilkaldt og spurgt om, hvorledes man skulde kontrollere Rigtigheden af Angivelserne om Valutatabet, og hertil svarede jeg, at man maatte vel kunne tage Skatteangivelserne til Udgangspunkt, saaledes dog at forstaa, at hvis Vedkommende paastod, at han havde ejet mere end det af ham skattemæssigt opgivne, maatte han kunne bevise eller fremskaffe Formodning om, at hans Opgivende nu var rigtigt, og at han havde lojet ved Skatteopgivningen. Heroverfor blev indvendt, at man fra dansk Side ikke havde følt sig højtideligt forpligtet til at opgive rigtigt, men det kunde jeg ikke anerkende Berettigelsen til, idet man jo ikke alene narrede Staten, men i hvert Fald ved kommunale Opgivender ogsaa Naboen. Resultatet blev vist, at man tog alt for meget Hensyn til mit Svar derved, at man følte sig 
alt for meget bundet af Selvangivelsen, i hvert Fald fik jeg det Indtryk, at man lidt for slavisk i Praksis fulgte denne, og at der, saavidt jeg forstod, maatte en ny Regulering til.

Hammerich meddelte mig, at det var bestemt, at jeg skulde forestaa Valutareguleringen i Sønderjylland. Dertil svarede jeg straks, at det kunde og vilde jeg ikke paatage mig. Det var jo kun en Ligning, som ikke havde min Interesse. Hammerich fastholdt sit, og der maa jo have været noget om det, thi Amtsforvalter Reimuth, der opholdt sig i Landsdelen for at tilrettelægge Skattevæsenet, meddelte mig ved en lille Middag, han ofrede paa mig, at saaledes hed det i den røde Bygning. Naar Juristerne, der forhørte sig hos Generaldirektør Koefoed om, hvem i Ministeriet, der skulde have den Opgave, havde Generaldirektøren, fortalte Reimuth, svaret, det skal Buuul. Han brugte saa mange u'er og viste dermed, at han ikke var tilfreds med Ordningen. Da Spørgsmaalet blev aktuelt, bad Amtmand Haarlev mig fra Koefoed om at komme til Haderslev og overtage Sagen - om det var for Landsdelen, som oprindelig tænkt, eller det nu var indskrænket til Haderslev, ved jeg ikke. Men jeg bad Amtmand Haarlev meddele Generaldirektøren, at det var jeg aldrig gaaet ind paa, og jeg kom ikke. Derefter hørte jeg ikke mere om den Ting.

Naar Amtsforvalter, eller den Gang Kontorchef, Reimuth, som før bemærket, gav en Middag til mig, var det som Tak for et Raad, jeg havde givet ham. Han bad mig en Gang længe før Middagen om at blive i Haderslev og ofre en Søndag paa ham. Han kendte mine Interesser for Skatteligningsprincippet (om det specielle Skatteproblem i Overgangstiden havde jeg iøvrigt skrevet en Artikel i Finanstidende, der i Landsdelen var blevet hilst med Tilfredshed). Nu skulde $\mathrm{Hr}$. Reimuth have et Møde med Amtmænd og andre kommunale Mænd om, hvorledes han vilde foreslaa Ordningen. Det, som han navnlig onskede mit Raad om, var, hvorledes han retfærdigt kunde dele Sol og Vind lige mellem paa den ene Side de 
sønderjydske Forretningsmænd, der en Del af Aaret havde handlet i Mark, og som havde set deres Marks Værdi forsvinde, og som nu skulde gøre deres Indkøb i Kroner, og paa den anden Side de Forretningsmænd fra det gamle Land, som kom med Kronerne og Varerne og derved havde en stor Chance forud.

Jeg gav ham da det Raad at lade de kongerigske betale Skat i Kroner af tjente Kroner og lade de sønderjydske betale Skatten af Kroneindtægten i Mark. Det vil sige - naturligvis ikke i Marksedler, men i Kroner efter en med Skatteafviklingen for $\emptyset$ je nærmere fastsat Kurs. Jeg nævnte udtrykkeligt, at Markens Bevægelser ikke skulde virke bestemmende paa den tilfældige Dag, hvor Betalingen skete. Dette tiltraadte Reimuth. Efter denne Drøftelse gik vi - Reimuth og jeg - efter indbyrdes Aftale for at faa Skøn af en klog Mand hen til Borgmester Holger Fink og forelagde ham Planen, som han straks forstod og godkendte som en god Løsning af dette for Sønderjyderne vigtige Problem.

Nogle Dage efter det Møde, Reimuth havde holdt med de vedkommende kommunale Mænd, rejste jeg, som ofte skete, i Toget med Amtmand Haarlev, og han fortalte mig da, at Reimuth havde fremsat et udmærket Forslag, hvilket han refererede, netop som jeg havde tænkt mig det.

Men jeg blev forfærdet, da jeg nogle Maaneder senere i Kroneudvalget mødte Referatet af Beslutningen, Derefter skulde der Uge for Uge fastsættes en Overkurs for Marken, der afleveredes til Skattebetaling. Uden at paaberaabe mig min Berettigelse som Ophavsmand til Ordningen, greb jeg straks ind for at paavise, at saaledes gik det ikke an. Men det var bestemt og fastlagt, og som P. O. A. Andersen og Hammerich bemærkede: Marken skal paa den Maade suges ud af Sønderjylland. Jeg kunde kun dertil svare, at den Form var vel den bedste til at suge Marken ind i Sønderjylland ad alle Revner og Sprækker. Den, der havde skilt sig af med Marksed- 
lerne, skulde altsaa til at købe op til Skattebetaling, og det gav da disse Sedler en unaturligt forøget Værdi. Saa vidt jeg forstod, blev alle Marksedlerne, der strømmede ind, oplagrede i Statskassen, til deres Værdi var Nul og Nix. Misforstaaelsen ærgrede mig, men mit Forslag var, hvis rigtigt fulgt, godt nok, og jeg kunde ikke gøre for, at det blev misbrugt.

Bedre Held havde jeg med Laanekassen og dens Forløber Kroneudvalget.

Da jeg en Gang i Slutningen af 1919 under Arbejdet for Kreditforeningens Start kom hjem til Lemvig fra en af mine mange Farter, fortalte min dygtige Kompagnon mig i sin Beretning, at han under mit Fravær havde arrangeret et Laan for en af vore Klienter, en Proprietær paa Egnen. Laanet var ordnet som et 3 Mdr.s Veksellaan til Vekselrenten i en lokal Bank. Beløbet var anvendt til Indløsning af den Markgæld, Klientens Paarørende havde $\mathrm{i}$ en Gaard i Sønderjylland, og Indløsningskursen var $30 \%$ eller lidt derover.

Samtidig fik jeg oplyst, at der i samme Bank paa tilsvarende Vilkaar var ordnet et Laan som Driftskapital til en sønderjydsk Forretningsmand, der vilde afvikle sin Markgæld og gøre Indkøb i Kroner.

At noget tilsvarende foregik andre Steder i de jydske Provinsbanker, havde jeg hørt, men den Omstændighed, at jeg her kom Sagen lige ind paa Livet gjorde, at jeg vaagnede til nøjere Eftertanke om det uholdbare i Ordninger af den Art.

Til dette bidrog ogsaa den Omstændighed, at jeg første Gang, jeg havde været sammen med Nis Nissen, benyttede Lejligheden til at spørge denne om, hvad han mente om Markkursens Skæbne. Dertil havde han svaret, at Kursen efter flere smaa Hop opad i tilsvarende større Fald nedad efterhaanden vilde glide ned til Nul.

Jeg havde nok fra anden kyndig Side hørt den stik modsatte Opfattelse gjort gældende, men jeg havde fæstet Tiltro til Nis Nissens Betragtning, der jo ogsaa viste sig at være rigtig. 
Jeg gav derfor overfor min Kompagnon Udtryk for, at Ordningen maaske ikke var saa klog, som den kunde have været. Dermed være dog ikke sagt, at jeg - hvis jeg havde været hjemme - turde have taget Ansvaret for at fraraade.

Dog vilde jeg nok i saa Fald have anført, at det antageligst var noget tidligt at indløse, da Chancerne for yderligere Fald i Markkursen var nærliggende, men det som navnlig gjorde mig betænkelig, var dels Ordningen til den høje Vekselrente, som muligt kunde komme til at gælde en rum Tid endnu, maaske kunde den endog blive forhøjet, og dels, at hvis Fornyelsen i en Bank af begrænset Format kunde blive vanskeliggjort, da var man først ude at svømme.

Den paagældende Sag var der imidlertid intet at ændre ved, men det stod mig klart, at en Fortsættelse ad den Vej for al sønderjydsk Markgæld kunde føre til en Katastrofe, som Staten til den Tid maatte tage sig af, og derfor var i mine Overvejelser Vejen oplagt til det Resultat, at Staten burde træde til med det samme for at regulere Oviergangen og yde Midlerne. Jo mere jeg kredsede om Emnet, jo mere klart stod dette for mig.

Da jeg næste Gang ganske kort efter kom til København og paa Hotel „Hafnia“ traf Dr. Karberg, med hvem jeg ofte ligesom med Holger Fink havde Drøftelser af den Art, betroede jeg mine Planer til ham, idet jeg hævdede, at der maatte gøres Skridt i den af mig tilsigtede Retning.

Dr. Karberg var straks meget interesseret og oplyste navnlig; at ret store Laan af tilsvarende Art, da Hovedstadsbankerne holdt sig tilbage, var ordnede $i$ Grænsebanker, der var ait for smaa til Opgaven i det Omfang, hvori det skete, og han havde hørt, at det skete til stigende Renter, der pro anno naaede 11 pCt. Altsaa en typisk og for Moderlandets Anseelse uværdig Udnyttelse af Situationen.

Næste Morgen stod vi begge tidligt op, Karberg for at rejse tilbage til Sønderjylland, jeg for at møde Callø ved Morgen- 
toget fra Haderslev. Der var en eller anden vigtig Ting, han og jeg skulde ordne sammen.

Mens vi om Morgenen drak Kaffe sammen, husker jeg, at Dr. Karberg spurgte, om jeg ikke mente, at man - altsaa før Genforeningen - a conto kunde udstede Kreditforeningsobligationer i Kroner, som derpaa kunde anvendes til Belaaning. Det var let for mig at paavise det umulige $\mathfrak{i}$ den Tanke. Nej, Staten maa træde til nu.

Ja, sagde Karberg, det maa Du saa tage dig af og vide, hvordan det skal gribes an.

For mig stod det klart, at det nu gjaldt om først og fremmest ikke alene at faa Smaabankernes Udnyttelse overflødiggjort, men tillige opnaa at udelukke Mulighederne for Storbankerne til Udnyttelse paa dette Omraade, naar Risikoen efter Genforeningen blev minimal. - Derfor maatte Laaneinstitutionen, der skulde tage sig af de af Genforeningen betrængte, saa vidt muligt oprettes med det samme. Da man imidlertid ikke kan starte en Laaneinstitution uden at have Udlaansmidler, maatte der tildeles de Mænd, som skulde overtage Ledelsen af Laaneforanstaltningen en midlertidig Opgave, og her foreslog jeg altsaa som Opgave Undersøgelsen af Omfanget af Smaabankernes hidtidige Laaneforanstaltninger og Rentekrav samt hele Tilrettelægningen af Genforeningens Økonomi, hvorigennem man kunde fastslaa, hvilke Midler der fra Statens Side maatte stilles til Disposition for de til Forberedelserne valgte Mænd.

At det ogsaa var H. P. Hanssens Opfattelse, at han med Udnævnelsen af Udvalgets Deltagere dermed valgte Laanekassens Bestyrelse, viste ikke alene, at netop disse Mænd med hans Billigelse uden videre overgik til Opgaven, da Sagen blev effektiv, men ogsaa, at han straks af Hensyn til Laaneinstitutionen vilde have en Bankkyndig med i Udvalget.

Da jeg altsaa samme Morgen, som Drøftelsen med Dr. Karberg var sket, mødte Callø paa Hovedbanegaarden, forelagde 
jeg ham mine Synspunkter og Planer, medens vi som forudbestemt fulgtes ad til Sønderjydsk Ministerium. Disse Planer billigede Callø. Vi kom straks ind til H. P. Hanssen, for hvem jeg refererede det, jeg foran har udviklet. H. P. Hanssen godkendte straks Planen, idet han samtidig fortalte, at han den samme Morgen havde modtaget et Brev fra Holger Fink, hvori denne, der var Formand for Handelsforeningen, havde været paa Linie med mig, idet han skrev, at det var nødvendigt, at der skaffedes Kronemidler til de sønderjydske Forretningsmænd.

H. P. Hanssen tog saa en Blok og spurgte mig, hvem skal vi saa sætte i det Udvalg. Han fortsatte: se Formanden udnævner Finansministeren, og dernæst skal Sønderjydsk Ministerium repræsenteres gennem Hammerich, saa skal De, Direktør Buhl, med som Forslagsstiller, og Karberg, nævnede jeg, idet jeg refererede vore Drøftelser, ja, Karberg, han kan jo have en Opgave som Repræsentant for tysk Jura. Endvidere Holger Fink for Handelsforeningerne og Refshauge for Landboforeningerne.*)

Men saa - bemærkede H. P. Hanssen - maa der, da det jo drejer sig om en Laaneinstiution, en Repræsentant for Bankvæsenet, men - fortsatte han - hvis Finansminister Brandes skal udpege denne, tager han Glückstadt, og det vilde være rarest at undgaa ham, og det kan vi ogsaa godt, da De Buhl, der jo er Bankdirektør, kan repræsentere den Opgave. H. P. Hanssen oplyste, at dette vilde han gøre gældende overfor Brandes. - (Ogsaa denne Ordning tiltraadte Bran-

*) Jeg havde paa Læben at spørge, om ikke Callø skulde med, men da han var til Stede, selv om han holdt sig passiv, fandt jeg det anmássende af mig. Hans Eksistens kunde H. P. Hanssen jo ikke have glemt saa lidt som Calløs Kvalifikationer dertil.

Men jeg fattede straks den Beslutning, at hvis Sagen blev effektiv, da at søge at faa ikke alene Callø, men ogsaa I. H. Schmidt og Refslund Poulsen ind. Dette Arbejde paabegyndte jeg overfor den valgte Formand P. O. A. Andersen, efter at Udnævnelserne forelaa. Men Gennemf $\phi$ relsen tog alt for lang Tid i Forhold til den afg $\phi$ rende Betyàning, som netop de tre Mænd fik for Sagen. 
des). Paa den „Landmandsbank“, Glückstadt i København hhv. jeg i Lemvig repræsenterede, var der ganske vist saa stor en Forskel som mellem en Elefant og en Kanin, men til Gengæld slog Elefanten den langt største Kolbøtte, da Forholdene senere afklaredes. (Kaninen blev senere solgt til Andelsbanken til Kurs 180). Naturligvis rettede jeg mig i Sædet, da jeg forstod, at jeg skulde remplacere Glückstadt, om hvis gedigne Storhed jeg dog allerede paa det Tidspunkt havde faaet en hel Del af den Tvivl, som H. P. Hanssen sikkert ogsaa har haft, og dette saa jeg allerede den Gang som Grunden til min Ophøjelse.

H. P. Hanssen erklærede, at han samme Dag vilde forelægge Forslaget for Finansminister Brandes, og han spurgte mig, om jeg havde noget særligt Ønske om, hvem der skulde blive Formand for Udvalget. Dog, tilføjede han, er det muligt, at han ingen Indflydelse fik derpaa, men han regnede med $i$ hvert Fald at faa Lejlighed til at fremhæve den, jeg eventuelt foretrak. Han mente, at Valget vilde komme til at staa mellem Generaldirektør Michael Koefoed og Statsgældsdirektør P. O. A. Andersen.

Jeg havde haft lidt med dem begge at gøre, mest med Koefoed, under hvis Skattevæsen jeg havde fungeret som Skatteraadsformand. Jeg kendte hans temperamentsfyldte Resoluthed, hvad der jo senere, da Kreditforeningens Skæbne stod paa Vippen, kom mig til Gode, fordi jeg vidste, hvorledes han skulde tages. Under ham, indsaa jeg, vilde Laanekassen og andre Problemer faa en resolut og hurtig Behandling og Afslutning, ligesom jeg mente at vide, at han nød stor Anseelse i Finanskredse.

Det sidste og meget vigtige mente jeg, kunde ikke, som det viste sig med Rette, i samme Grad siges om P. O. A. Andersen; man var noget tilbøjelig til, næppe uden Grund, at smile af hans mange Ben, men her vilde der paa den anden Side ik- 
ke blive Tale om at begrænse Sagen til mindst muligt (tværtimod), men navnlig om ikke at jage Sagen igennem.

Jeg svarede $H$. P. Hanssen efter bedste Overbevisning, at hvis jeg maatte vælge, tog jeg Koefoed.

Senere paa Dagen traf jeg atter H. P. Hanssen ved en festlig Lejlighed. Han meddelte mig da, at Brandes straks havde akcepteret min Plan, men at det var P. O. A. Andersen, som vilde blive Formand. Denne havde nemlig anmodet Brandes om at faa en Opgave under Genforeningen, og Koefoed havde allerede faaet Anmodning om at forestaa Valutareguleringen. H. P. Hanssen oplyste, at jeg snarest vilde faa min Udnævnelse som Medlem af Udvalget, og at der snarest muligt vilde blive indkaldt til det første Møde den sidste Lørdag før Jul.

Ved min Hjemkomst fik jeg den officielle Meddelelse, der nøje indeholdt Linierne $\mathrm{i}$ mit mundtligt fremsatte Forslag, idet den var saalydende:

Det midlertidige Ministerium

for

sønderjydske Anliggender.

Kjøbenhavn, den 19. December 1919.

Under Henvisning til stedfundne mundtlige Forhandlinger beskikker Ministeriet Dem herved til Medlem af et Udvalg med den Opgave

1) at foretage en nøje Undersøgelse af, hvor mange og hvor store Kronelaan Sønderjyderne har optaget her i Kongeriget, og under hvilke Former og paa hvilke Vilkaar de er optagne,

2) at bistaa Sønderjyderne med Opretholdelsen af en midlertidig Kronekredit paa rimelige Vilkaar og

3) i det hele at overveje og eventuelt stille Forslag om, hvilke Foranstaltninger der bør og kan foretages for at gøre Overgangen fra Mark til Krone saa let som muligt for det økonomiske Liv i Sønderjylland,

hvilket herved meddeles Dem, idet tilføjes, at Departe- 
menschef, Statsgældsdirektør P. O. A. Andersen er beskikket til Formand for Udvalget, samt at Møde afholdes i Udvalget førstkommende Lørdag Kl. 3 Eftermiddag i dette Ministeriums Lokaler, Niels Juelsgade 3, I.

H. P. Hanssen.

Hr. Sagfører Orla Buhl,

/ M. Hammerich.

Lemvig.

Da Dr. Karberg og jeg mødtes paa Hotel „Hafnia“ Dagen før den i Skrivelsen til Møde berammede Lørdag, satte vi os $i$ en sen Aftentime til at udarbejde Koncepten til den Rundskrivelse, der til Opfyldelse af Opgavens Post 1 skulde udsenaes til Pengeinstitutionerne for at faa oplyst, hvad der var laant og paa hvilke Vilkaar. Dette gjorde vi for dermed at fremme det egentlige Formaal, Laanene paa rimelige Vilkaar. Disse Koncepter afgav vi inden Mødet næste Dag til Hammerich. Indhentningen af Oplysningerne blev dog overdraget Nordslesvigsk Kreditforening, og da de var indhentede, saa vidt det lod sig gøre, kom Laanekassen. Den egentlige Hensigt med Foranstaltningen, som jeg havde tænkt mig den, var dermed naaet, og Udvalget konstituerede sig uden videre som Laanekassebestyrelse. Da Laanekassen skulde starte, blev Udkast til Laaneblanketter m. v. rundsendt. Jeg havde, jeg tror 14 Rettelser at foreslaa. De blev alle akcepterede. Om Laanekassens Betydning og mulige Fejl i Tilrettelægningen skal jeg andetsteds udtale mig.

Med Hensyn til Udnævnelsens 3die Del at fremsætte Forslag om, hvilke Foranstaltninger der bør og kan foretages for at lette Overgangen fra Mark til Krone, tør jeg vist sige, at Udvalget iøvrigt ikke (altsaa udover det tilsigtede - forberede og tiltræde Ledelsen af Laanekassen) kom til at spille nogen afgørende Rolle.

Det blev imidlertid tilfældigvis den Del, der kom til at give Udvalget Navn. Det blev nuv. Landsretssagfører, fhv. 
Borgmester Thulstrup i Haderslev, der den Gang var ansat i det sønderjydske Ministerium, som paa det første Møde, det eneste Møde, hvori han som Sekretær deltog, der har \#Fren herfor, idet han foreslog "Kroneudvalget“, en god kort Betegnelse, der straks blev akcepteret. Jeg vilde dog have foretrukket "Kronelaansudvalget" for at fastholde Hovedopgaven. Men da det jo netop var Kroner, som man skulde have til Disposition gennem Laanekassen, var Navnet jo udmærket. Og man kan ikke skille Kroneudvalg og Laanekasse ad. De var fødte samtidigt, og da man vedtog at overtage Ledelsen af Laanekassen som Bestyrelse, bestemte man fremdeles at varetage ogsaa andre Genforeningen vedrørende Interesser, naar saadanne faldt for. Hvad ogsaa skete og fik Betydning.

Ved Valutareguleringen, for at se paa andre Opgaver, kunde der fra Kroneudvalgets Side ikke røres. Den Sag sorterede jo under Generaldirektør Koefoed. Og denne skulde sikkert i meget bestemt Form have reageret, hvis Statsgældsdirektøren havde søgt at influere her.

Skatteproblemet kunde man ogsaa med Ro have holdt sig fra. Det sorterede under daværende Kontorchef Reimuth, og denne havde som før nævnt og sikkert i rigtig Form forelagt sit udmærkede Forslag for Administrator og andre af Landsdelens Autoriteter, og der faaet det godkendt. Hvor det blev ændret, forinden det blev refereret i Kroneudvalget, ved jeg ikke, men da Hammerich var enig i den førnævnte Ændring, maa det vel være under Passagen gennem det sønderjydske Ministerium.

Paa et vist Tidspunkt ønskede Formanden P. O. A. Andersen en Konference med Nationalbanken. Et fra hans Side set naturligt Ønske.

Dette Ønske meddelte Hammerich mig. Han oplyste, at han af Formanden havde faaet den Opgave at tilsige Nationalbankdirektør, Dr. Ussing. Den Opgave, sagde han, er jeg ked af, og han tvivlede iøvrigt om, at Dr. Ussing overhove- 
det vilde møde, i hvert Fald ikke efter en skriftlig Tilsigelse fra P. O. A. Andersen. Der er Blod mellem de to Mænd, fortalte Hammerich, og Ussing er jo ikke til at spøge med. Hammerich spurgte, om jeg ikke vilde gaa med over i Nationalbanken, saa var vi jo en lille Deputation, der kunde indbyde ham. Det gik jeg med til. - Dr. Ussing rankede sig i Sædet og havde vist noget ikke imødekommende paa Læberne, da Hammerich meget snildt havde forebragt Ønsket. Men Dr. Ussing sank det bitre og lovede at komme. Jeg holdt mig helt passiv, som min Opgave var.

Men Mødet forløb ikke helt smertefrit.

Dr. Ussing medte paa Klokkeslet den 23. Januar 1920. Han satte sig lidt tvært paa den ham af Formanden anviste Plads for Enden af Bordet til højre for P. O. A. Denne rejste sig og i smukke Ord takkede han Nationalbanken, fordi den havde stillet sig forstaaende og imødekommende overfor Landsdelen.

Derpaa svarede Dr. Ussing stadigt siddende langsomt og roligt, idet han til en Begyndelse saa lige ud over Bordet: „Naar Nationalbanken stiller sig imødekommende overfor Sønderjylland, er det, fordi det er vor Pligt. og for Udførelsen af vor Pligt skal vi ingen Tak have" (idet han nu drejede Hovedet til venstre lige ind i Ansigtet paa Formanden, tilføjede han hurtigt), "specielt ikke af $D$ e $m^{\prime \prime}$.

Naa! Det tog P. O. A. som en Mand, han gik videre.

Men Sangbunden var forstemt.

Som jeg senere skal vende tilbage til, havde jeg ved et forudliggende Møde allerede fremlagt en Exposé om den Stabilisering af Kreditforeningsobligationerne, der senere blev effektiv, og da der intet herom af Formanden blev bragt paa Bane, kunde jeg ikke dy mig for at udnytte Lejligheden til at komme i direkte Rapport til Nationalbanken, og, som det hedder i Protokollen, fremkom Buhl paany med Tanken om 
Belaaning eventuelt gennem Skadesløsbreve, som i de faste Ejendomme skulde stille en bankmæssig Sikkerhed, som muligt kunde accepteres af Nationalbanken.

Medens mit Forslag om Belaaning af Kreditforeningsobligationerne imidlertid, som det siger sig selv, var tænkt som noget, der skulde foranstaltes efter Genforeningen, var det Spørgsmaal, jeg rejste overfor Dr. Ussing, et Forsøg paa allerede nu at skaffe Laan til de betrængte i Landsdelen, altsaa uden at behøve at vente paa Laanekassen, selv om den var paa Trapperne.

Noget stort Haab havde jeg jo ikke. - Var i Virkelighede selv klar over, at om nogen Sikkerhed, der kunde tilfredsstille Nationalbankens Laaneregler, kunde der ikke blive Tale, men anden Mulighed var der jo ikke.

Imidlertid hørte Dr. Ussing tilsyneladende med stor Interesse paa mit Indlæg, og han lovede iflg. Protokollen at drøfte Spørgsmaalet med sine Kolleger og muligt komme til et Resultat.

Dette hørtes der dog intet fra paa den Foranledning.

Derimod havde dette Møde den Interesse, at Dr. Ussing - som han selv oplyste - huskede mig, da vi senere, som efterfølgende skal vise, fik Brug for ham.

Der kunde jo ikke siges noget til, at Statsgældsdirektøren efter hans Indstilling og med den Berettigelse, Post 3 gav, vilde søge at tage sig af Kreditforeningens Interesser. At jeg ikke ønskede hans Indblanding, er en Sag for sig.

Jeg bestemte mig til, navnlig efter at være blevet bekendt med Forholdet til Nationalbanken, i muligt Omfang at passe pala, at han ikke kom til at blande sig mere end nødvendigt i disse Forhold.

Og jeg fik straks Brug for min Aarvaagenhed.

Paa det første Møde i Kroneudvalget den 20. Decbr. 1919 foreslog Formanden, altsaa P. O. A. Andersen, at man søgte 
Forbindelse med samtlige Storbanker og Staten om Overtagelsen af de første 10 Millioner Kroner af Sønderjyllands Kreditforenings Obligationer.

Dertil bemærkede jeg, at Kreditforeningen allerede havde henvendt sig til og truffet Aftale med Landmandsbanken, og at jeg ansaa det for heldigst kun at have een Forbindelse. Endvidere gjorde jeg opmærksom paa, at jeg ansaa det for vigtigere at søge at faa etableret en Mulighed for en Belaaning af Kassseobligationerne for derfra at regulere Salget (som jeg betegneds, gennem en Tragt, der kun afgav, hvad Markedet kunde taale uden alt for stort Fald), altsaa for at forhindre, at Salget skete til en Kurs, der blev præget af det store Salg. Og jeg gjorde opmærksom paa, at Sagen jo ikke var klaret blot ved at faa solgt til Dagens Kurs. Hvis denne blev lav i Startøjeblikket, var det vigtigere at faa Salget udskudt. Endvidere var det jo ikke blot de første 10 Millioner, der gerne skulde sælges godt. Callø havde, oplyste jeg, anslaaet det første Aars Udlaan til 40 Milioner, og det at faa Storbankerne til at dele Købet af 10 Millioner mellem sig, kunde jo resultere i, netop naar man delte Interessen paa flere Hænder, at hvis Kur$s \in r$ steg, solgte de igen for at stryge Fortjenesten, saaledes at Kursen tilsvarende faldt under Salget af de sidste 30 Millioner. Det, som skulde opnaas, var en fast Placering til god Kurs, men Hovedstadsbankerne havde jo hver for sig andre Kreditforeningers Interesser at passe, og af disse Kreditforeninger var flere mod Oprettelsen af Sønderjyllands Kreditforening og vilde næppe billige en saadan Interesse for os.

Jeg har altid holdt paa, at man gør klogt $i$ at nøjes med een Bankforbindelse, den bedste man kan faa. Dette var et hos mig fastlagt Standpunkt. Jeg har ogsaa ved anden Lejlighed hævdet dette, idet jeg med Virkning har brugt den Sammenligning, at man lige saa lidt skal have Maskepi med flere Banker som med flere Kærester. I begge Forhold stikker de 
nemlig af allesammen, naar det kniber for en, og man netop har mest Brug for dem, Kæresterne ligesom Bankerne henviser $\mathrm{i}$ en Krisesituation til de andre, man indlod sig med. Det kan ingen af dem med Rette gøre, naar man har været trofast mod den ene, som man i gode Tider har sluttet sig til.

Mine Ræsonnementer blev faktisk godkendte. P. O. A. Andersen havde intet at bemærke dertil, men foreslog tværtimod, at han og Dr. Karberg, der den Gang boede i Sønderborg, dannede et Udvalg, som skulde forhandle med Bankerne. som det i Protokollen hed, efter Direktør Buhls Forslag. At dette ikke huede mig, behøver jeg vist ikke at oplyse. Jeg var vist saa indbildsk at mene, at jeg vist var bedst til at gaa mine egne Erinder selv.

Paa et senere Møde i Kroneudvalget den 5. Januar har P. O. A. gjort nogle Bemærkninger om, hvorledes han tænkte sig Udvalget, bestaaende af Dr. Karberg og Formanden, skulde virke. Saa længe det stod paa disse Forberedelser, var der jo ingen Skade sket.

Hvad "Planerne“ gik ud paa, erindrer jeg ikke. P. O. A. havde en Tilbojelighed til indledende at give orienterende $\mathrm{Be}-$ mærkninger. Hvor gennemtænkte de var forinden, ved jeg jo ikke, men det kunde hænde, at hvis et Medlem, navnlig een af de sønderjydske Repræsentanter, kom med en eneste afbrydende Bemærkning eller blot en Rømning, der viste, at han ikke var enig, kunde P. O. A. meget behændigt iøvrigt dreje om og resultere $\mathrm{i}$ orienterende at fastslaa det stik modsatte af det, Indledningen - saa vidt man maatte forstaa den beredte.

Lykkeligvis foretog Formanden sig intet i Spørgsmaalet Bankordningen. Jeg betroede mig den Gang til Dr. Karberg om min Frygt for, hvad der kunde laves af Ulykker, hvis „Udvalget" gav sig til at optræde. Ordningen med Landmandsbanken var jeg som tidligere sagt, ikke glad ved, men en Sammenrod- 
ning af Bankerne, uha! Dr. Karberg trøstede mig med, at han ikke havde hørt (og aldrig siden hørte) om Udvalgets Virksomhed, saa det skulde jeg ikke være bange for.

Efter Indledningen den 5. 1. 1920 om, hvad Formanden orienterende havde tænkt sig, drøftedes ifølge Protokollen, hvilke Foranstaltninger der kunde tages for at støtte den nye Kreditforening ved Placeringen af dens Kasseobligationer.

En af Direktør Buhl affattet Exposé om Stabiliseringen af Obligationerne oplæstes og sattes - iflg. Protokollen - under Debat.

Fremdeles ifl. Protokollen udformede Direktør Buhls Exposé nærmere den af ham i sidste Møde fremsatte Tanke, at Staten skulde belaane den nye Kreditforenings Obligationer til en nærmere bestemt god Kurs og til samme Rente, som Obligationernes Kupons lød paa.

Formanden (P. O. A. Andersen) nærede Tvivl om, at Bankerne gik med hertil, ogsaa vilde Staten sikkert have Betænkeligheder. Han vilde foretrække fast Overtagelse af første Post og senere - om fornødent - maaske Belaaning. Direktør Buhl forsvarede Belaaningsforslaget og tilføjede stadig iflg. Protokollen: Hvis Kursniveauet her hjemme i det givne Øjeblik var særlig lavt, vilde Sønderjyderne - der skulde tage' deres Laan hjem og ikke, som det i mange Tilfælde fandt Sted i Kongeriget, under lave Kurser kunde lægge $\mathrm{K}$. Obligationeme til Side og afvente bedre Tider — føle sig noget skuffede, - navnlig hvis Kurserne forholdsvis snart efter gik i Vejret. Denne Kalamitet undgik man ved Belaaning, naar denne vel at mærke skete f. Eks. til Dagens fulde Kurs til omtalte lave Rente.

Hertil vil Formanden have bemærket som noget, han vidste, at en Bedring i Kursen vilde tage et á to Aar. - Andet end Taler om, hvad man kunde tænke sig at gøre, skete der lykkeligvis ikke. 
Men saa kom det os venligt sindede Ministeriums Fald, og med dette faldt Kurserne katastrofalt.

Da vi, Callø og jeg, paa dette Tidspunkt (men før det værste Kursfald) var til Møde i København, blev vi enige om at gaa hen i Landmandsbanken og høre, hvilke „Hjælpeforanstaltninger" denne vor Forbindelse havde i Beredskab for os. Vi bad Holger Fink om at gaa med.

I Landmandsbanken bad vi om at hilse paa Direktør Ringberg, med hvem den oprindelige "Aftale“ var truffet. Dette var ugørligt, og det viste sig jo ogsaa senere, at D'Hrr. havde ganske andre Ting at tænke paa..

Vi blev saa vist ned i Kælderen hos en Underdirektør, der havde med disse Ting - Fondsvæsnet - at gøre. Der var ingen Tvivl om, at vi kom til Ulejlighed. Dette viste Underdirektøren eller rettere søgte at skjule ved at tage overlegent paa Tingen. Det, han navnlig lod os vide, var, at Banken først og fremmest havde at sørge for sine gamle Kreditforeningsforbindelser, og at der intetsomhelst kunde siges om vore Kurser ud over, at de vilde blive betydeligt lavere end de tilsvarende $i$ andre Kreditforeninger. Callø gjorde opmærksom paa, at det af Ringberg var lovet, at man skulde søge at holde Kurs med tilsvarende Kreditforeninger, og han og Underdirektøren kørte haabløst rundt i Sagen uden Mulighed for Kontakt. Der var ingen Naade for os. Da dette havde foregaaet en Tid, tillod jeg mig for at høre om Stillingen til det, hvorom der var rent Tilsagn, at spørge, om Underdirektøren kendte Direktør Ringbergs bestemte Løfte om, at Landmandsbanken vilde overtage de første $200.000 \mathrm{Kr}$. til Vest- og sønderjydsk Kreditforenings Kurs den paagældende Dag. Nej - det kendte han ikke noget til, og det kunde han ikke love noget om. Kan vi da ikke komme til at tale med Direktør Ringberg, spurgte jeg. Nej - ganske umuligt. Derefter sagde jeg saa henvendt til Callø og Fink, men til Efterretning for Underdirektøren: „Saa 
mener jeg, at vi bør gaa, for her synes der jo ikke at være mere at tale om “. Og saa gik vi - tavse et Stykke hen ad Gaden, indtil Callø bemærkede: hvad nu. Dertil svarede jeg, nu skal vi til Nationalbanken og faa den til Forbindelse. Tror Du, det lader sig gøre, spurgte Callo. Det ved jeg ikke, men jeg ved, det er vor eneste Udvej, hvis vi overhovedet skal kunne starte.

Vi tog hjem, jeg til Lemvig, men begge med det bag Øret, at vi snart maatte gore et nyt Forsøg i København. Callo meddelte mig, at han senere havde truffet en anden Underdirektør i Landmandsbanken, og med denne havde han prøvet paa at indlede en Dreftelse om Kurserne. Underdirektøren havde imidlertid givet det Svar, at efter Direktor Buhls agressive Optræden i Landmandsbanken, regnede Banken ikke mere med Forbindelse med Sønderjyllands Kreditforening. Da Callø refererede dette, svarede jeg, at jeg fandt, at det var rart at have dette Forhold klarlagt. Og efter nyt Kursfald mødtes Callø og jeg i Kobenhavn for at faa en Ordning.

Og der gik altsaa vi to smaa Mænd en skønne Morgen fra Hotellet mod Nationalbanken. H. P. Hanssen var afgaaet som Minister og sad i Aabenraa. Vor gode Ven, Indenrigsminister Ove Rode, var afskediget, og Senderjydsk Ministerium var blot et Ekspeditionskontor, der likviderede. Kursen faldt stadig. Humøret i tilsvarende Grad.

Da vi kom til Nationalbankens Stentrappe, stoppede vi op, fordi Callø bemærkede, om det dog ikke var rigtigst først at gaa til Landmandsbanken, for, spurgte han - har Du tænkt paa, at hvis det mislykkes her i Nationalbanken, kan vi ikke derefter gaa tilbage til Landmandsbanken. Dertil svarede jeg, at det har jeg netop tænkt paa, og Du har Ret i, at vi ikke kan gaa tilbage til Landmandsbanken. Jeg kan nemlig ikke gaa med, men her er det jo saa heldigt, at jeg ikke har afbrudt Forbindelsen med Lemvig. Der kan jeg vende tilbage til, og Du kan gaa til Landmandsbanken og med fuld Sandhed give mig 
Skylden for den eventuelle forrykte Henvendelse i Nationalbanken. Ja lad os saa gaa der ind, men Du skal føre Ordet, sagde Callø.

Vi fik straks Foretræde for Dr. Ussing, der taalmodigt hørte paa hele min Udvikling. Hans prægtige stærke og kloge Ansigt røbede ikke meget om Svaret, men det lidet, som det viste, var Forstaaelse, Interesse og Velvilje.

Jeg fortalte om Landmandsbankens Stilling til os - som jeg klogeligen ikke da kritiserede, men tvært imod udtalte, at vi, som det laa, godt forstod den, ligesom vi var klar over, at en tilsvarende Stilling maatte de andre Banker, nu da det kneb for alle, tage af Hensyn til deres gamle Kreditforenings-Forbindelser.

Men jeg fastslog, at den eneste Udvej, vi herefter saa, var den, at Nationalbanken overtog Forbindelsen uden Mellemled. Her tror jeg dog, at Dr. Ussing spærrede Øjnene lidt mere op. Jo, sagde jeg, det maa den for at faa $\mathrm{K}$. Obligationerne solgt til samme Kurs som tilsvarende Kreditforenings K. Obligationer. Noget andet vilde være at bedrage den Landsdel, som nu ikke skal have Tillægslaan til Forbedring, som kan udskydes, men som helt skal belaanes. Derfor maa Nationalbanken for ikke at tvinge til utilfredsstillende Salg og opelske et generelt Fald Landet over p. Gr. af de store Poster, der kommer paa Markedet, stille det fornødne Beløb til Disposition for Belaaning af forste Aars Udlaan. Hvor meget, spurgte Dir. Ussing - 40 Millioner, svarede Callø. Og fortsatte jeg: Disse Laan maa ydes, saaledes at Laantageren faar mindst den Kurs udbetalt, som han kunde opnaa ved Salg i Dag, og dette Laan maa han have til en Rente, som Kuponen dækker. D. v. s., at han i Dag og fremdeles, til Kursen bliver brugelig, stilles mindst lige saa godt, som hvis han havde solgt, og dertil faar han Chancen for at faa den senere opnaaede højere Kurs udbetalt. For at holde Kursen oppe er det, at vi vil henstille til Nationalbanken, at den stiller et Beløb paa f. 
Eks. 10 Millioner til Brug ved Støttekøb. Salget skulde jo gerne kunne reguleres saaledes, at man ikke ved at forhaste sig dermed bragte Kursen i Fare. Det bedste var, om Nationalbanken vilde paatage sig at lade Salget foregaa i den Orden, Belaaningen var sket. Det, som jeg kaldte, at Obligationerne skulde tragtes ud paa Markedet.

Dir. Ussing gav intet Svar ud over et Løfte om, at han den samme Dag skulde drøfte Sagen med sine Kolleger. Kun spurgte han, til hvem af D'Hrr. skal jeg sende Svaret. Til Direktør Buhl i Lemvig, vi tager nemlig begge hjem i Aften, svarede Callø. Da vi kom ned i Nationalbankens store Hall, sagde jeg til Callø. Det Brev, vi faar efter dette ene Besøg, kan jeg skrive paa Stedet. Det bliver i første Omgang et pænt Afslag, som vi skal over at drøfte igen, hvis vi skal klare Sagen. Men saa kan Tiden være forpasset. Derfor foreslog jeg, at vi ventede endnu en Dag med at rejse, og da vi var enige herom, gik jeg ind i den Boks, der findes i Bankens Forhal og ringede op til Dir. Ussing, som jeg meddelte, at vi ikke rejste, samt spurgte, hvornaar vi personligt maatte afhente hans Svar. Vi fik Tid næste Dag Kl. 2.

Og Kl. 2 sad vi der igen, og saa fik vi Svaret. - Dir. Ussing oplyste i den venlige Form, hvori man meddeler Familien om en kær Paarørendes Død, at han og hans Kolleger havde indset, at den Sag var saa vigtig, at Nationalbankens Direktion havde anset sig forpligtet til at sammenkalde Hovedstadsbankernes Direktører og forelægge dem Problemet. Svaret var blevet, at man sikkert maatte regne med, at Sønderjyllands Kreditforenings $\mathrm{K}$. Obligationer vilde faa en Kurs, der laa ca. 4 Points under tilsvarende Kreditforeningers Obligationer.

Med Hensyn til Spørgsmaalet om Nationalbankens Overtagelse af Forbindelsen direkte med Sønderjyllands Kreditforening, fortsatte Dir. Ussing, vilde noget saadant være en ganske ekstraordinær Foranstaltning, som Nationalbanken iøvrigt ikke havde Apparatet til. 
Det at paatage sig at stille Millioner til Disposition til Køb og Salg til Fordel for en enkelt Kreditforening, laa helt udenfor de Opgaver, som Nationalbanken ifølge sin Oktroj havde Berettigelse til, det maatte, hvis det skulde praktiseres, være en Statsopgave.

Derimod var det at udlaane mod Haandpant naturligvis noget, der laa indenfor Opgaven, men da dette Ønske var knyttet til de øvrige Krav, var der næppe Grund til at drøfte, om der kunde blive Tale om de af Direktør Buhl ønskede Betingelser, altsaa hvad Laaneprocenten og Renten angik.

Det vilde altsaa sige, at vi i dette hellige Øjeblik havde modtaget et pure Afslag og dermed faktisk en Meddelelse om, at Sønderjyllands Kreditforening var at opgive. Jeg følte mig den Gang overbevist om, at D'Hrr. Bankdirektører var gaaet hjem fra Mødet Dagen før med den Tanke, at nu var den Sag klaret, som D'Hrr. ønskede den. At dette ogsaa var Calløs Opfattelse, kunde jeg se paa ham.

Det skal vi dog nappes om, tænkte jeg. Saa gjorde jeg mig saa dristig til Calløs store Forundring at svare, at jeg var glad ved den Forstaaelse, der ret beset paa alle Omraaderne lyste ud af Doktorens Svar. Denne, der ikke var let at bringe ud af Fatning, saa maaske dog lidt desorienteret ud.

Jeg fortsatte. Thi det, som altsaa krævedes for Muligheden af at faa Nationalbanken til Forbindelse: en ekstraordinær Situation, møder vi jo med. Vi staar her over for den mest elsstraordinære Situation, som nogensinde vil kunne opstaa i Forhold af denne Art. Det vilde hos Sønderjyderne blive betragtet som den allerstørste Hæder og vække den største Betryggelse, naar netop Nationalbanken gik direkte ind, og iøvrigt kræver Nødvendigheden dette og dette navnlig efter de andre Bankers Svar. Nationalbanken er jo den eneste, som ikke har andre Kreditforeningers Kurser at passe.

M. H. t. de praktiske Vanskeligheder, at Banken ikke havde Apparatet, fortsatte jeg, lod disse sig vel overvinde. Ja, sva- 
rede $\mathrm{Dr}$, Ussing, der her gik i Skred, det kunde jo nok om saa skulde være, ordnes gennem en Vekselerer, og som et straalende Bevis paa, at vi havde ham med os, tilføjede han, hvilket Firma han i saa Fald vilde tænke paa..

De sagde, fortsatte jeg, at Fremskaffelsen af et Millionbeløb til gennem Opkøb at højne Kursen var en Statsopgave. Maa jeg spørge, om vi maa forstaa det saaledes, at De vil gaa med til det øvrige, Udlaanet og Forbindelsen, hvis der fra Staten kan fremskaffes et Tilsagn om de 10 Millioner Kroner dertil.

Svaret lød. Det kan jeg naturligvis ikke love Dem, Direkter Buhl, for det har vi i Direktionen ikke drøftet nærmere indbyrdes, men jeg vil love Dem, at hvis De kan komme med et saadant Tilbud fra Staten, skal Spørgsmaalet i sin Helhed blive taget op til ny velvillig Behandling. Og tilføjede han, som Medlem af Kroneudvalget og den - jeg husker det fra Mødet i Kroneudvalget, hvor jeg var til Stede - der har fremsat denne Plan, maa De jo kunne forfølge den videre overfor Staten. Tak, det maa vi jo arbejde paa, sagde jeg. Og saa gik vi.

$\mathrm{Nu}$ skal vi op til (den under Overgangen fungerende Finansminister) Generaldirektør Koefoed, sagde jeg til Callø, Imidlertid vil jeg helst have, at vi havde haft et mere solidt Mandat, altsaa at vi ikke skulde nøjes med den Fuldmagt, Dir. Ussing faktisk havde givet mig til at optræde overfor Staten. Jeg vidste, at P. O. A. Andersen var bortrejst. Men jeg gik op til Hammerich i det fhv. sønderjydske Ministeriums Lokaler. Hammerich var Næstformand i Kroneudvalget. Jeg fortalte ham kort, hvad der var foretaget og spurgte, om han som Næstformand vilde billige, at jeg gik til den fungerende Finansminister om denne Sag. Hammerich kunde ikke skjule, at han var stødt over, hvad jeg i Forvejen havde foretaget mig uden at lade det gaa igennem Kroneudvalget, han vilde i hvert Fald tværtimod modsætte sig, at jeg paa dette Udvalgs Vegne foretog mig videre. Dertil var intet at sige. P. O. A. vilde aldrig selv have givet den, saa lidt som jeg vilde have anmodet ham der- 
om. Han vilde tværtimod selv have blandet sig i Sagen, og ingen ved, eller rettere jeg troede at vide, hvad det i saa Fald var resulteret $i$.

Godt, sagde jeg til Hammerich, saa kan og skal jeg altsaa ikke støtte mig til Kroneudvalget, men Kreditforeningen maa jo have Lov til selvstændig at varetage sine Interesser, og jeg oplyste, at paa denne Institutions Vegne vilde jeg foreslaa Callø, at han og jeg rettede Henvendelsen. Det ved jeg, at vi ikkє behøver at spørge Kroneudvalget om, sagde jeg.

Og bedst var det vel nok, at Kroneudvalget ogsaa her holdtes udenfor. Jeg vidste jo, at Forholdet mellem de to vidt forskellige Mænd, Generaldirektør Koefoed og Statsgældsdirektør P. O. A. Andersen, ikke var bedre end dertil. Det var efter min Mening tidligt nok, naar Sagen var ordnet, og Formaliteterne skulde udveksles, at P. O. A. og Kroneudvalget traadte til. lovrigt havde Dir. Ussing - sikkert ikke uden en vis Forstaaelse af Situationen - berørt Muligheden af, at jeg gik til Koefoed. Sagen hastede nemlig, og jeg har aldrig været slem til at lade Formaliteterne lægge sig paa tværs af Realiteterne. Det var bestemt ikke noget, der maatte udsættes, ikke til der var dannet en ny Regering (f. Eks. I. C. Christensen). Jernet var gloende.

Noget andet var, at jeg selv ikke var særlig stolt af at rette Henvendelsen. Husk, at det nu var Knald eller Fald. Vi var næsten vennelose med Fjender, mægtige Fjender i Hobetal. Jeg kendte Generaldirektør Koefoeds korte Maade at afgøre Tingene paa, og dette Kendskab bestemte jeg mig til benytte mig af. Jeg spurgte Callø, om jeg ogsaa her skulde føre Ordet, - ja absolut. Men saa maa Du ikke blive forfærdet, hvis jeg sætter Trumf paa, sagde jeg. Gør, som Du vil.

Vi kom saa ind til den fungerende Finansminister, og jeg gav en meget kort Fremstilling af, hvad der laa forud, idet jeg saa hurtigt som muligt og forsætligt lidt brutalt kom til Pointet i det Spørgsmaal: Vil Staten stille 10 Millioner til Disposition 
til gradvis Opkøb af Sønderjyllands Kreditforeningsobligationer for derigennem at holde Kursen oppe. Finansministeren optraadte i første Omgang, som jeg havde ventet. Han slog med en udslettende og afvisende Bevægelse ud med begge Hænder og svarede „absolut Nej“. „Nu har Valutaordningen kostet den danske Stat (jeg husker ikke hvor mange Millioner) og mere skal der ikke ofres paa den Ting“.

Det forstaar vi, svarede jeg, nøjagtigt lige saa absolut som Ministeren, - men vil Finansministeren saa ikke gøre os den Tjeneste at hjælpe os til at faa Oprettelsen af Sønderjyllands Kreditforening standset, thi skal Landsdelens Laanetrang realiseres til de af Finansmændene bebudede Kurser eventuelt 4 pCt. under de foreliggende stadigt dalende Kurser, er det en saa daarlig Tjeneste at gøre Mændene dernede, at vi i hvert Fald ikke vil være med dertil. Og føjede jeg til, dette tør vel siges ikke at være Udførelsen af en Direktørinteresse (noget, der fra anden Kreditforenings Side offentligt var fremsat som Motiveringen til Konkurrentens Oprettelse). Virkningen blev den ventede.

Dette her er nok Alvor, sagde Finansminister Koefoed med et helt andet Tonefald, lad os tale om Tingene. Og saa talte vi sammen en Time $i$ en hel anden Tone og fik gjort Ministeren begribeligt, at det at imødekomme os absolut ikke behøvede at betyde $\mathrm{Tab}$ for Staten, men tværtimod kunde blive (og blev) til Millionfortjeneste. Men efterhaanden forstod han i det Hele, hvilke Fordele denne faktisk lille Tjeneste fra Statens Side iøvrigt kunde betyde i Retning af Nationalbankens Forbindelse og midlertidige Laan paa omtalte Betingelser.

Hele Synspunktet anerkendte han. Og klart laa det jo, at skulde Staten støtte, skulde det netop ske gennem en Bank, der kun havde denne Forbindelse, altsaa Nationalbanken.

Hans Slutningsbemærkning var følgende. Ja, D'Hrr. ved jo, at jeg kun er Finansminister i Uger, maaske kun Dage, saa De forstaar, at jeg ikke som saadan kan afgøre Sagen, men naar 
jeg ikke længere er Finansminister, er jeg atter Departementschef, og det første jeg vil gøre, lover jeg Dem, skal være at forelægge Deres Ønske for den kommende Finansminister, og jeg skal selv gaa i Breschen for dets Opfyldelse.

Dermed var faktisk Sønderjyllands Kreditforening frelst ud af den største Fare, den nogensinde har været i eller kan komme i. Og i den Følelse gik vi. Nu var det kun at vente paa den nye Regering. Henvendelsen til Kroneudvalget lod jeg i Bero. Det var for stor en Risiko, om man derfra vilde til at virke.

Men da der nogen Tid efter blev sammenkaldt til et Kroneudvalgsmøde, bad jeg Hammerich om dertil at indbyde Callø, der som førnævnt mærkværdigvis ikke var Medlem af Kroneudvalget (men som jeg før har oplyst, senere blev Medlem sammen med I. H. Schmidt og Refslund Poulsen). Ønsket om at faa Callø med til Kroneudvalgsmødet var selvfølgeligt fra min Side. Nu var det nødvendigt, nu turde jeg sætte Formanden ind i mit Arbejde. Og her skulde Callø med. Hammerich havde ikke spurgt mig om, hvad jeg fik ud af Henvendelsen til Koefoed og jeg ikke meddelt det.

Den 8. Maj 1920 afholdtes dette Møde. Imidlertid var den nye Regering med Neergaard som Statsminister udnævnt.

Paa Dagsordenen var opført Spørgsmaalet om Sønderjyllands Kreditforenings Obligationer. Jeg bad Hammerich om, at dette Spørgsmaal maatte blive behandlet ved Formiddagsmødet. Ikke desto mindre blev flere - ret ligegyldige - Sager bchandlede først, og dette tog Formiddagen. Saa var der Frokostpavse, og først derefter kom Sagen om Sønderjyllands Kreditforenings Obligationer for. Formanden, der altsaa intet kendte til, hvad Callø og jeg havde foretaget os, kom med en lang Udvikling om Salg til Sparekasserne af bestemte Partier til Dagens Kurs og andet deslige, der ikke havde Hold i Realiteter, idet der intet overfor disse Institutioner var forberedt. Endeligt fik jeg efter flere Anmodninger Ordet. Og uden 
at ænse Formandens lange Indledning om Sparekassernes eventuelle Køb afgav jeg en saa kort og koncis Redegørelse, som det var muligt efter Hensynet til alle Momenter i Sagen med Nationalbanken og Minister Koefoed. - Jeg henstillede, at man skulde søge en Drøftelse med Nationalbanken for at faa officielt bekræftet, at den, som det var stillet i Udsigt, var villig til at overtage Forbindelsen og yde Laanene paa de af mig omtalte Vilkaar, ligesom jeg henstillede, at man burde søge Forbindelse med den lige udnævnte Finansminister Neergaard om dennes Stilling til den Indstilling, Koefoed havde lovet at afgive. - Og jeg skal love for, at der blev Gang i Støvlerne. De i Luften svævende Sparekasseordninger blev glemte. Direktør Bech (Kolding) blev af Formanden, længe før jeg var færdig, straks sendt ud til Telefonen for at forhøre hos Nationalbanken, om vi kunde komme der over til en Konference. Ligesom der blev ringet til Finansministeren. Mødet i Nationalbanken blev berammet til Afholdelse med det samme, og før jeg havde afsluttet, satte vi i Lab der over og blev vist ind $i$ Repræsentantskabssalen. Og der sad vi altsaa i de høje Lænestole, Kroneudvalget + Callø paa den ene Side af det brede lange Bord, og paa den anden Side Nationalbankdirektørerne Winther, Rubin, Ussing og Stephensen.

P. O. A. indledede selvfølgeligt og fulgte ret godt, men meget svævende det, som jeg lige forinden havde haft Lejlighed til at fremstille for ham. Naar jeg var nervøs for, hvad der kunde komme, var det, fordi jeg ansaa det for nødvendigt, at man gik ud fra, at der under Forudsætning af, at Statens Tilsagn om 10 Mill. Kroner kom til at foreligge, var givet Tilsagn om det for P. O. A. ganske nye Nationalbankovertagelsen af Forbindelsen og de billige procentvis store Laan. - Jeg onskede ikke, at der skulde opstaa Diskussion herom. Men jeg havde jo ikke haft Lejlighed til at fuldende min Fremstilling i Kroneudvalget, fordi Mødet blev berammet omgaaende.

Heldigvis løb P. O. A. ret hurtigt tom, idet han bemærkede, 
at da Planen, vi kom for, var Direktør Buhls, saa han gerne, om denne selv vilde forelægge den. Dette var jeg jo ikke forberedt paa, men da jeg jo kendte mine Ting, skilte jeg mig vist, efter hvad der blev sagt, helt pænt derfra, og jeg fik under denne Redegørelse fremstillet de særligt gunstige Betingelser for Laanene i Nationalbanken, alt under Forudsætning af, at Staten ydede de 10 Mill., ligesom jeg fastslog, at jeg gik ud fra, at Nationalbanken i København skulde have Opgaven (at være Tragten) at sælge, naar man der i den Orden, Indleveringen var sket, fandt det klogt. Dette førte til, at man kastede sig over dette Problem, altsaa sprang det ovrige (som vedtaget) over. Spørgsmaalet var altsaa ikke Forbindelsen med Nationalbanken (under Forudsætning af de 10 Mill.), men om vi skulde have Midlerne indtil 40 Millioner til Disposition. Her skete det, at Direktør Bech (Kolding), der ikke havde hørt min Fremstilling ved Mødet, desværre kom ind paa, at Udførelsen burde ske gennem hans Filial i Kolding, og dette optog den største Del af Mødet. Der var ogsaa et andet underordnet Problem, hvor Direktør Winther fastslog, at jeg havde Ret.

Efter mig talte Callø støttende og nærmere udviklende om mit. Han gjorde det klart og klogt, saa det undrede mig, at han bag efter sagde til mig: Det var godt, at det var dig, der skulde tale først. Jeg var straks saa imponeret over, at vi sad her og talte paa lige Fod med Nationalbankens høje Direktører, ai jeg tror, jeg ikke kunde have talt. Det var en Levning fra den tyske Tid, som Callø hurtigt gjorde sig fri for.

Til Slut bemærkede Nationalbankdirektør Winther, at vi nok kunde regne med, at Nationalbanken (under Forudsætning af de 10 Mill. fra Staten) paatog sig Forbindelsen, at der blev stillet os indtil 40 Millioner Kroner til Disposition (uden at der blev taget Forbehold mod mine Vilkaar. Tværtimod husker jeg, at en af Direktørerne bad mig uddybe en enkelt Ting af de af mig foreslaaede Laanevilkaar. Disse fik han uden at reagere). Dog krævede Nationalbanken, at i saa Fald skulde 
Sønaierjyllands Kreditforenings Direktion og ikke Nationalbanken disponere over Salgstiden. Saa vidt jeg husker, blev P. O. A. Andersen, allerede mens vi sad i Nationalbanken eller umiddelbart derefter kaldt til Telefonen for efter Forespørgsel at modtage den Besked fra Statsministeriet, at Sagen om de 10 Millioner paa Koefoeds Indstilling var i Orden. I hvert Fald havde P. O. A. faaet Beskeden, da jeg samme Aften rejste hjem og traf ham $i$ Toget. Han skjulte ikke, at han fandt, at jeg havde manøvreret klogt i den Sag, men heller ikke, at han meget gerne havde set, at jeg havde ladet den gaa gennem ham. Paa en Maade havde jeg lidt ondt af Manden, hvis gode Vilje jeg ikke skal bestride, men jeg maatte handle, som jeg gjorde, fordi jeg saa saaledes paa det, at hvis Sagen ikke netop var grebet an, som det skete, og netop paa det Tidspunkt, hvori det skete, vilde Sønderjyllands Kreditforening enten aldrig været blevet til, eller hvad der havde været værre, være blevet en svagelig maaske dødfødt Institution, som jeg i hvert Fald vilde have betakket mig for Deltagelse i.

$\mathrm{Da}$ de første Obligationer skulde sælges, blev det overdraget mig at rejse til København for at drøfte Kursen, desværre ikke med Nationalbanken, men med Statsgældsdirektør P. O. A. Andersen og Vexeleren. Jeg husker, at Henriques hos Statsgældsdirektøren, hvor Mødet holdtes, mødte med en Opstilling af alle tilsvarende Kreditforeningsserier. Han havde regnet Dagens Gennemsnitskurs ud. Jeg blev spurgt, om jeg kunde godkende den. Jeg opdagede da, at een af Kreditforeningerne maaske paa Grund af en særlig uheldig Børsdag, havde en betydelig lavere Kurs end de ovrige. Og jeg tog da min Blyant og slog en Streg over dette Tal og svarede, ja hvis det Tal gaar ud af Beregningen. Hvor meget det hævede Gennemsnitskursen, husker jeg ikke, men vi kom meget lidt paafaldende op i Forhold til vor Nabokollega, og det husker jeg, 
var Callø ikke saa glad ved. Han mente, vi burde have startet under en beskednere Kurs.

Jeg forstod ikke Callø, men jeg tav. Det drejede sig om den Bagatel, der gjorde, at vi i Starten dokumenterede, at vi ansaa vore Obligationer som lige saa gode som Øernes og ikke paa Forhaand vilde lide under den Kritik, der paa dette Tidspunkt herskede over for Vest- og sønderjydsk Kreditforenings noget for højtspændte Udlaan. - En Kritik, der under denne Kreditforenings indledende Udlaan i Tønder Amt fik sin $\mathrm{Be}^{-}$ kræftelse derved, at disse i første Omgang blev saa høje, at vi maatte holde os noget tilbage. Vi kunde ikke være med i Vognen. - Og lad os endelig ikke tro, at den lille Kursforhøjelse har nogetsomhelst med det Fald at gøre, der senere en Overgang kom. - Dette havde sine naturlige Grunde, som jeg skal vende tilbage til.

Det er rigtigt, at vi ikke under Haandpantsætninger opnaaede saa gunstige Laanevilkaar hos Nationalbanken, som jeg havde foreslaaet, og som jeg havde Lov til at gaa ud fra, at Nationalbanken faktisk var gaaet med til.

Men for at opnaa dette, skulde der have været hamret videre las paa den Kile, hvad der ikke blev. Dette vanskeliggjordes derved, at Filialen i Kolding fik Held af sit Ønske om at være Centralen for Belaaningen. - $\mathrm{Da}$ var det nærliggende at regne med, at saa kom det let til at gaa paa den for Filialen sædvanlige Trommerum. Men de 40 Millioner var i hvert Fald derigennem stillet til Disposition. Naar dette $i$ alt for liden Grad blev udnyttet, skyldes det særlige Grunde. En meget væsentlig Grund hertil var, at der udadtil intet blev gjort for at gøre Laaneformen og dens Fordele bekendt.

Da Ordningen langt senere blev oplyst paa en Generalforsamling, blev der da ogsaa rettet Kritik mod Direktionen, fordi dette var fortiet. Men da var Tiden forpasset.

Men dertil kom navnlig, at "Tragten“ sprængtes. Min af Dr. Ussing fuldt forstaaede Tanke var jo den, at Nationalban- 
ken i København skulde modtage alle Sønderjyllands første Aars Kasseobligationer og belaane dem under den af mig foreslaaede Form, der samtidig med, at den ikke havde beredt Nationalbanken en Øres Tab, havde givet Laantageren en fra Tabsmulighed udelukket fin Chance. Laantageren havde faaet det samme Provenu udbetalt, som hvis han havde solgt, og han bevarede Muligheden for uden Rentetab at opnaa yderligere Provenu, hvis Kursen steg. Der skulde - ifølge min fremstillede Plan - ikke sælges een Obligation paa Børsen eller direkte, hvis Kursen kom under Tidens allerfineste Kurs - Salget skulde foregaa i den Orden. Obligationerne indkom fra Kreditforeningen.

En saadan Ordning kunde have været Laantagerne paatvungne ved Kreditforeningens Start, men denne Mulighed var forpasset og laa ikke for. Hvis den skulde have været indført senere, maatte det ske ad Frivilighedens Vej bl. a. og navnlig ved Henvendelse til de lokale Banker, der forberedte Laanene. Men for det første skete en saadan Henvendelse, saa vidt jeg ved, ikke, og for det andet og navnlig var det mere end tvivlsomt, at disse Banker vilde lade sig fravriste de Provisioner, de kunde beregne sig ved direkte Salg. - Og lave en Ordning for de villige og lade de andre have frit Spil, vilde jo sige, at "de andre" de uvillige, alene nappede Fordelen ved Opkøbet gennem de 10 Millioner. Derfor var det i Virkeligheden rigtig og nødvendigt, da disse andre masede paa for at nyde Fordelen, for en Tid at opgive Opkøbet og lade Kursen falde. - Dette havde paa den anden Side den Fejl, at under denne Lavkurs var det en nærliggende Fristelse for de, der vidste, at Opkøbet vilde begynde paany og Kursen stige, at købe til Lavkursen og saa sælge til Højkursen, og man maa ikke glemme, at en halv Procents Stigning paa 2 Dage svarer til en Rente af $180 \%$ p. a. Saa Fristelsen for den velvidende Inderkreds var stor.

Altsaa der skulde have været holdt paa intet Salg under slet 
Kurs, og de Salg, der skete, skulde i videste Omfang ske til Sønderjylland venligt indstillede Institutioner, der ikke søgte Gevinst paa Landsdelens Bekostning. Men naar Sagen skulde ordnes, som den blev det, var alle extraordinære Foranstaltninger vanskeliggjorte.

Det rigtige havde jo været, at een Mand eller nogle Mænd i Nationalbanken Dag for Dag bestemte, hvad der skulde ske m. H. t. Køb og Salg, ligesom disse besørgede Videresalg af Beholdningen til foran nævnte venligt sindede Institutioner. - Den eller disse Mænd maatte ikke have anden Interesse i Kursstigning og Fald.

At mine Planer altsaa ikke blev gennemførte i det Omfang, vi havde tilrettelagt det og haabet det, skal ikke nægtes. At den oprindelige Plan har været bemærket og senere drøftet med Interesse, ved jeg, fordi jeg flere Aar efter har været anmodet om at gengive den. Imidlertid maatte jeg samtidigt oplyse, at dér, hvor den var paatænkt, kunde den ikke bruges. Det kunde den rigtigt forstaaet og rigtigt startet i Tide overfor den ene Opgave, jeg her sigtede paa.

Men jeg maa have Lov til at beklage, at alt for faa af de $\mathbf{4 0}$ Millioner kom ind under Ordningen, som den nu blev. De, som benyttede den, tjente vist mellem 10 à $15 \%$. Den Omstændighed, at Staten kunde tjene de samme Procenter ved det utidige Videresalg, viser ogsaa, hvad der rigtigt udnyttet kunde have været tjent for Landsdelen.

Imidlertid var ogsaa denne Del af Ordningen, seiv om den bjev for lidt udnyttet, af stor Interesse for rette Vedkommende. Dertil kommer - hvad der ikke maa glemmes - at Ordningen med de 10 Millioner til Disposition fra Statens Side var en Betingelse for at komme igen til Nationalbanken og faa denne Bank til Forbindelse.

Hvis man inden for Nationalbanken (saaledes som jeg oprindeligt havde tænkt mig det, men som jeg maatte erkende næppe var foreneligt med dens Oktroj) havde paataget sig Opgaven 
at administrere de 10 Millioner til Støttekøb og i størst mulig Udstrækning det direke Salg til Sønderjyllands mange Venner, der ikke tænkte paa Videresalg, var i hvert Fald et for Landsdelen skæbnesvangert Fejlgreb undgaaet.

Ved Bedømmelsen af den Betydning, det af Callø og mig trufne Arrangement fik, maa ogsaa de her bristede Forudsætninger om Udøvernes Forstaaelse tages i Betragtning.

Der kan spørges, om det ikke havde været bedre, hvis vi ikke som det første Skridt havde henvendt os til Landmandsbanken, men var gaaet til en af de andre Storbanker.

Jeg tror hertil at kunne svare, at som det udviklede sig, var det netop et Held, at vi indledte dér; Landmandsbanken kunde vi komme fra og kom fra, fordi den var syg. Det var ikke gaaet saa let med en af de andre, der ikke var i Landmandsbankens Knibe.

Man havde ikke derfra optraadt saa nervøst og taabeligt (som det skete $\mathrm{i}$ Landmandsbanken), at vi kunde tillade os at bryde brat af.

Vi havde i saa Fald ogsaa andetsteds faaet reserverede men uafviselige Tilsagn, men hvorledes Resultatet var blevet, fik de paagældende Banker jo Lejlighed til at dokumentere under det af Dr. Ussing sammenkaldte Møde efter vort første Besøg hos ham.

Bankerne onsker jo hver for sig saa mange Forbindelser med Kreditforeninger som muligt.

Det er vist saaledes, at Kreditforeningerne mener, at Bankerne betragter det som deres Hovedopgave at skaffe Debitorerne højst mulig Kurs, og i den Udstrækning dette kan forenes med Opgaven at skaffe deres Kunder og Købere lavest mulig Kurs, slaar Opfattelsen sikkert ogsaa til.

Var det blevet saaledes, at Nationalbanken direkte havde udøvet Opgaven med at skaffe Laantagerne højst mulig Kurs, havde jeg med endnu større Beklagelse, end Tilfældet var, set 
paa, at Handelsbanken (ad hvilke Veje det skete er mig ubekendt) senere fik gennemført, at denne Bank skulde overtage Forbindelsen og Indskrivningen. Den sidste Opgaves Løsning gennem Nationalbanken havde jo givet vore Obligationer en særlig Glans.

Derfor foreslog jeg, da Flytningen var uundgaaelig, at $i$ hvert Fald denne Opgave (Indskrivningen) fremdeles skulde forblive i Nationalbanken. Men det kunde der ikke være Tale om.

Saa blev vi enige om, at vi skulde spørge Nationalbanken, om den dog ikke fremdeles vilde beholde Indskrivninger forsaavidt de Kasseobligations-Kreditorer angik, der alt havde Indskrivning dér. Det gjorde vi, og hertil svarede Dr. Ussing (der ikke skjulte eller rettere udtalte, at man godt vilde have beholdt det Hele), at hvis vi onskede det, vilde man fremdeles fortsætte med de Forbindelser, der m. H. t. Indskrivning alt var knyttede til hans Bank.

Derefter gik vi over til Handelsbanken, men Direktør Nørregaard blev vred, da vi tog Forbeholdet. Nationalbanken beholdt dog Opgaven flere Aar derefter.

I det Hele meldte Hovedstadsbankerne sig i indbyrdes Kapløb, da Genforeningen var i Orden. - Kapløbet skete med en saadan Iver, at de kom saa langt ud i Risiko, at man fra deres Side skønnede, at nu maatte der findes en Ordning - formelt af Hensyn til Sønderjyderne, reelt i nogen Grad af Hensyn til Bankerne.

Og saa nedsatte man da en Kommission, der af en eller anden mærkværdig Grund blev kaldt „Realkredit"- Kommissionen.

Jeg tror at turde sige, at jeg allerede den Gang betragtede det som givet, at den Løsning (Hypotheklaanefonden), som jeg blev Forslagstiller til, maatte blive Resultatet, hvis det skulde 
være rigtigt. Jeg uddybede naturligvis ikke Tanken paa dette Tidspunkt. Der sad jo en Kommission, og jeg var klar over, at min Indblanding ikke vilde være velkommen.

Men saa kom Betænkningen, der løste Sagen ikke saa meget gennem Realkredit som med det modsatte i Kaution. Altsaa Hovedstadsbankernes Risiko blev efter dette afløst af Slægt og Venners Kautionsrisiko. - Da man indsaa, at dette ikke var nogen hverken fyldestgørende eller tiltalende Løsning, men en man skulde bort fra saa snart som muligt, fremkom der fra forskellige Sider flere, men alle uanvendelige Forslag.

Saa bestemte jeg mig til at gøre som Soldaten, der, da det gik skidt under Krigen, købte en Kanon og begyndte for sig selv, idet jeg til Callø sendte Rammerne og Motivering til mit Forslag, ikke helt det i Bogen om Kreditforeningen optagne, men det, som blev Resultatet, nemlig Loven om Sønderjydsk Hypothek-Laanefond, dog med beklagelige \#ndringer i. Callø og Realkreditkommissionens Formand, som Callø ønskede tilkaldt, havde straks Indvendinger, som jeg absolut ikke kunde anerkende. Kommissionsformanden erklærede, at han fremfor mine Løsninger, naar saa skulde være, foretrak Driftslaaneforeninger med samt disses Solidaritet.

Her havde jeg fra tidligere Praksis Erfaringer, hvis Rigtighed de derefter gjorte Forsøg da ogsaa paaviste. Der er tre Slags Driftslaaneforeninger: I. med ene solide Medlemmer, som altsaa ikke behøver Pengene, men laaner p. Gr. af den billige Kente, altsaa Rentemisbrug. II. Driftslaaneforeninger med ene usolide Medlemmer, der snyder Statskassen for Kapitalen, men lykkeligvis uden at skade de andre Medlemmer. De behøver alle sammen kun at slaa paa deres tomme Lommer, altsaa Svindel. (Da jeg en Gang under en af de Drøftelser, hvortil Stauning Tid til anden tilkaldte mig, gennemgik dette Emne, udbrød han her: Ja, det har De sandelig Ret $i$, vi har lige haft en saadan Forening, hvor hver eneste Øre blev tabt. Det var ikke alene 
alle sammen insolvente Medlemmer, men for de flestes Vedkommende var det nærmest Forbrydere).

Løsning Nr. III var den mest beklagelige Form. Foreninger, hvor der baade er solide og usolide Medlemmer. Her drager de usolide de solide med i den Ulykke, som disse sidste selv kunde have klaret sig fri af, hvis de havde været holdt udenfor og ingen Hjælpeaktion var etableret. Altsaa Solidaritetsmisbrug.

Driftslaaneforeningerne blev forsøgt, men blev ikke rigtigt til noget, før man indsaa, at heller ikke under denne Kautionsog Solidaritetsform var Løsning at finde.

Og saa blev det dog Idéen og Princippet i min oprindelige Plan, der sejrede. - Saaledes som Callø ogsaa loyalt erkender i Bogen om Kreditforeningen.

Men desværre lykkedes det under Udførelsen at hindre Indførelsen af den af mig foreslaaede Kasseobligationsform, der her kunde have beredt „Tragten"s Indførelse fra første Færd i Bestræbelsen henimod Pariudbetaling til Laantagerne og gennem Kasseobligationer Mulighed for billigere Indløsningspris gennem Opkøb. Men den Endring, som oprindeligt bekymrede mig mest var, at ogsaa her skulde indbyrdes Solidaritet indføres og blev det. Tænk, hvis man ikke under Praktiseringen havde forspildt og faktisk droppet denne Forpligtelse, altsaa at Landsdelens Laantagere havde haft Forpligtelse til at betale de tabte Poster. Paa slige Bestemmelser kan ingen værdig Statshjælpeforanstaltning bygges.

Man maa være enig med mig i, at naar det offentlige under en Situation vil hjælpe, maa man ikke gøre det ved gennem Kaution at drage en Mand, som ellers kunde have klaret sig selv, ind $\mathrm{i}$ den Ulykke, som Laantageren, han kautionerer for, blev skaanet for gennem Laanet.

Man maa ogsaa erkende, at tilsvarende Kautionsforpligtelser under Sønderjyllands Laanekasse er forfejlede og ikke bør forfølges, i hvert Fald ikke til nogen Grad af Yderlighed. Man 
bør holde sig Laanekassens oprindelige Opgave for $\varnothing \mathrm{je}$, den at laane til dem, der ikke kan laane andetsteds.

Begrænset Solidaritet indenfor 1. Prioritet kan være forsvarlig og nyttig. Men allerede naar man kommer til 2. Prioritet, er den betænkelig. Og under $\mathrm{Hj}$ ælpeforanstaltninger forkastelig.

Alle de tre Institutioner, Kreditforeningen, Laanekassen og Hypotheklaanefonden blev kun skabte til Udnyttelse for Landsdelen. Man kan derfor sige, at vi, der arbejdede for deres Oprettelse, ikke dermed har bidraget til Genforeningens fornemste Opgave - Udslettelsen af den gamle Grænse.

Hypotheklaane-Institutionen vil ifølge sine Vedtægter ebbe uã af sig selv. -

Ogsaa Sønderjyllands Laanekasse var i Formen oprettet som en midlertidig Institution. Men jeg tror at turde sige, at H. P. Hanssen allerede ved den allerførste Dag i dens Historie i December 1919 i sit Hjerte saa paa dette Spørgsmaal ligesom jeg, at det vilde gaa, som det ofte er gaaet i tilsvarende Forhold, at Institutioner af den Art faktisk kan være lettere at faa oprettet end ophævet.

Og det vilde for Laanekassens Vedkommende være forkert at arbejde derpaa. - Der kan jo være Perioder, hvor Hovedopgaven er Afvikling, men det har altid vist sig, at der kan komme nye Situationer, hvor det for Landsdelen er en Lykke, at Apparatet er til Stede.

Der er det unaturlige i Laanekassens Ledelse, at Afgørelserne træffes i København og dér paa Grundlag af Papirer, medens Vurderingskyndigheden og det lokale Kendskab ligger hos Borgerne i Landsdelen, der maatte være de mest kvalificerede ikke alene til Indstillinger, men ogsaa til det endelige Skøn.

I Modsætning til de to andre Institutioner har Sønderjyllands Kreditforening ingen Tidsbegrænsning. Den maa regnes som evigt virkende. Og en Lykke for Landsdelen har den væ- 
ret. Her er Vurdering, lokal Kyndighed og Afgørelsen til Stede hos Repræsentantskabet og Direktørerne Callø og Hans Hansen. Da Kreditforeningen blev oprettet, skulde der efter Loven være tre Direktører, og jeg blev altsaa den tredie. Ved anden L.ejlighed har jeg paralliseret min Betydning til selve Kreditforeningen med det 3die Hjul til en Gig. Hvad der fra anden Side kan have været og Gang paa Gang er blevet sagt til Forsvar for min Tilstedeværelse, endogsaa udover alle Aldersgrænser, maa de paagældende selv tage Ansvaret for. $\mathrm{Na}$ turligvis har jeg paahørt dette med Glæde. Men navnlig har det glædet mig, at alle Institutionens Grene fra først til sidst har vist, at man mente det, og har handlet derefter.

Dog bør det maaske ogsaa siges til Forsvar for min trods alt i dette Forhold rolige Samvittighed, at jeg gennem den samme lange Periode ikke har været uden Indflydelse paa forskellige andre Omraader, navnlig overfor Lovgivningen med Hensyn til Krisebestemmelseme, Henstandsvæsnet, Prioritetsbegrænsningen, konjunkturbestemt Rente, Konverteringsproblemet, Akkordordninger og m. m., og at jeg herigennem stadig havde Udslettelsen af den gamle Grænse for Øje, dette, selv om - eller maaske netop fordi - jeg særligt sigtede paa Landsdelens Interesser.

Men alt dette er en Historie for sig selv. 